\title{
Twenty-five years of Mercator ocean reanalysis GLORYS12 at Drake Passage: Velocity assessment and total volume transport
}

\author{
Camila Artana, Ramiro Ferrari, Clément Bricaud, Jean-Michel Lellouche, \\ Gilles Garric, Nathalie Sennéchael, Jae Hak Lee, Young-Hyang Park, \\ Christine Provost
}

\section{To cite this version:}

Camila Artana, Ramiro Ferrari, Clément Bricaud, Jean-Michel Lellouche, Gilles Garric, et al.. Twentyfive years of Mercator ocean reanalysis GLORYS12 at Drake Passage: Velocity assessment and total volume transport. Advances in Space Research, Elsevier, 2019, 10.1016/j.asr.2019.11.033 . hal03015364

\section{HAL Id: hal-03015364 \\ https://hal.archives-ouvertes.fr/hal-03015364}

Submitted on 19 Nov 2020

HAL is a multi-disciplinary open access archive for the deposit and dissemination of scientific research documents, whether they are published or not. The documents may come from teaching and research institutions in France or abroad, or from public or private research centers.
L'archive ouverte pluridisciplinaire HAL, est destinée au dépôt et à la diffusion de documents scientifiques de niveau recherche, publiés ou non, émanant des établissements d'enseignement et de recherche français ou étrangers, des laboratoires publics ou privés. 


\title{
Twenty-five years of Mercator ocean reanalysis GLORYS12 at Drake Passage: Velocity assessment and total volume transport
}

\author{
Camila Artana $^{\mathrm{a}, *}$, Ramiro Ferrari ${ }^{\mathrm{b}}$, Clément Bricaud ${ }^{\mathrm{c}}$, Jean-Michel Lellouche ${ }^{\mathrm{c}}$, \\ Gilles Garric $^{c}$, Nathalie Sennéchael ${ }^{\mathrm{a}}$, Jae-Hak Lee ${ }^{\mathrm{d}}$, Young-Hyang Park ${ }^{\mathrm{a}}$, \\ Christine Provost ${ }^{\mathrm{a}, *}$ \\ ${ }^{a}$ Laboratoire LOCEAN-IPSL, Sorbonne Université, (UPMC, Université Paris 6), CNRS, IRD, MNHN, Paris, France \\ ${ }^{\mathrm{b}}$ CIMA/CONICET-UBA and UMI IFAECI-3351, Buenos Aires, Argentina \\ ${ }^{\mathrm{c}}$ MERCATOR-OCEAN, Parc Technologique du Canal, Ramonville St. Agne, France \\ ${ }^{\mathrm{d}}$ KIOST, Busan, South Korea
}

Received 12 June 2019; received in revised form 14 November 2019; accepted 22 November 2019

\begin{abstract}
Velocities in Drake Passage from the 25-year GLORYS12 Mercator Ocean reanalysis were compared with satellite altimetry-derived surface velocities and independent in-situ velocity measurements from the DRAKE (2006-2009) and cDrake (2007-2011) experiments. GLORYS12 assimilates satellite along-track sea level anomalies and, as expected, model velocities are in rather good agreement with gridded altimetry derived velocities ( $\mathrm{r} \sim 0.5$, above $99 \%$ confidence level). GLORYS12 velocities also compared well with the currentmeter data from the DRAKE (in the water column) and cDrake ( $50 \mathrm{~m}$ above seafloor) experiments in terms of means and standard deviations; most correlations between the reanalysis and directly measured velocity time series were significant $(\mathrm{r} \sim 0.5$ for DRAKE and $\mathrm{r} \sim 0.4$ for cDrake, above $99 \%$ confidence level). We used the GLORYS12 reanalysis to examine the Antarctic Circumpolar Current (ACC) total volume transport across three sections in Drake Passage. The 25 years of the ACC total volume transport has a mean of $155 \pm 3 \mathrm{~Sv}$ and a standard deviation of $6.7 \mathrm{~Sv}$. Annual mean values span over a range of $12 \mathrm{~Sv}$. The spectrum of the GLORYS12 total transport time series shows energy peaks (above 95\% confidence level) at the intraseasonal, semi-annual and annual periods and no significant low-frequency variations (beyond 2 years) or trend, in agreement with previous studies. This first assessment of GLORYS12 velocities in Drake Passage is very encouraging for monitoring the regional variability of the ACC.
\end{abstract}

Keywords: Satellite altimetry; Ocean reanalysis; Antarctic Circumpolar Current; Volume transport; Drake Passage

\section{Introduction}

The Antarctic Circumpolar Current (ACC), the largest wind-driven current in the world oceans, circumnavigates

\footnotetext{
* Corresponding authors.

E-mail addresses: cartlod@locean-ipsl.upmc.fr (C. Artana), ramiro. ferrari@cima.fcen.uba.ar(R.Ferrari),clement.bricaud@mercator-ocean.fr (C. Bricaud), jean-michel.lellouche@mercator-ocean.fr (J.-M. Lellouche), ggarric@mercator-ocean.fr (G. Garric), nas@locean-ipsl.upmc.fr (N. Sennéchael), jhlee@kiost.ac.kr (J.-H. Lee),yhpark@mnhn.fr (Y.-H. Park), cp@locean-ipsl.upmc.fr (C. Provost).
}

around Antarctica. It plays an important role in global climate by connecting the three major oceans, transporting heat, momentum and biological/chemical properties. Located between the South American and Antarctic continents, Drake Passage (DP) connects the southeastern Pacific and the southwestern Atlantic. It is the narrowest stretch of water (by about $850 \mathrm{~km}$ ) separating Antarctica from the northern continents (Fig. 1). DP is shallower than the upstream basin in the Pacific and is ringed by a system of ridges (Fig. 1). Gaps in these ridges are essential in determining flow patterns. The Shackleton Fracture Zone 
(SFZ), a narrow ridge rising several hundreds to thousands of meters above the seafloor, occupies a central position in DP. It intersects the Phoenix-Antarctic Ridge (PAR) to the west and the West Scotia ridge to the east (Fig. 1).

DP acts as one of five major choke points for the ACC (Park et al., 2019) and logistically it is the most practical location to monitor the full meridional extent of the ACC. Consequently, DP has been the most intensively sampled region of the Southern Ocean. Hydrography and mooring data from the landmark DRAKE 79 field experiment made as part of the International Southern Ocean Study (ISOS) provided fundamental insights into the spatial and temporal structure of the flow and the first estimation of the mean and standard deviation of the total ACC volume transport at DP: $134 \mathrm{~Sv}\left(1 \mathrm{~Sv}=10^{6} \mathrm{~m}^{3} / \mathrm{s}\right)$ with a standard deviation of $11 \mathrm{~Sv}$ for a year-long record in 1979 (Whitworth, 1983; Whitworth and Peterson, 1985). The range of uncertainty on the mean was established to lie between 15 and $27 \mathrm{~Sv}$ (Cunningham et al., 2003). Later, lowered acoustic Doppler current profilers (LADCP) from hydrographic cruises provided high vertical resolution fulldepth current observations and led to instantaneous total volume transport estimates mostly between 130 and
$150 \mathrm{~Sv}$, similar values to that of the DRAKE 79 field experiment (e.g., Cunningham et al., 2003; Renault et al., 2011).

The satellite altimetry era brought new perspectives to the monitoring of the ACC circulation and its transport variability through DP (e.g. Sprintall, 2003; Chouaib et al. 2006; Sokolov and Rintoul, 2009; Barré et al., 2011). The main goal of the DRAKE project (Provost et al., 2011) was to take advantage of the altimetric time series initiated in 1992 to estimate a volume transport time series of the ACC in DP. Hydrographic data and current meter time series were collected during 3 years (20062009) in the upper $3000 \mathrm{~m}$ of the water column along the ground-track \#104 of the Jason satellite altimeter to the east of the SFZ (Fig. 1, red section and white dots). The DRAKE in situ data have been used to evaluate the altimetric products. Both hydrographic data and current meter data showed that altimetric data, and in particular multi-satellite gridded products provided accurate information on sea surface height and surface velocity variations (Barré et al., 2011; Ferrari et al., 2012, 2013). The first 20 -year long time series of the ACC volume transport at DP (1992-2012) in the upper $3000 \mathrm{~m}$ was obtained by combining in situ ( 3 years of current meter moorings) and satel-

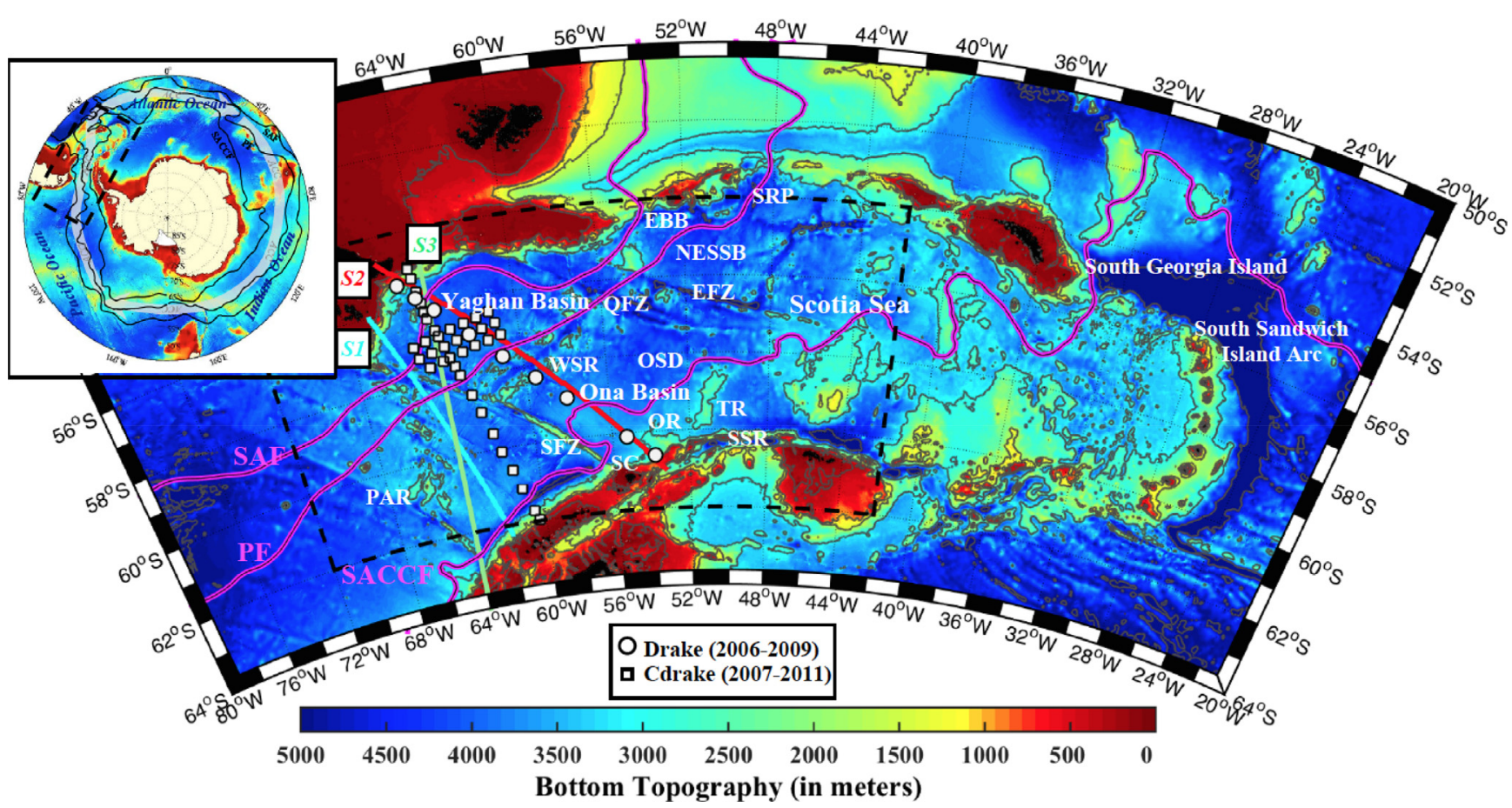

Fig. 1. Location of moorings from DRAKE 2006-2009 (white circles) and cDrake 2007-2011 (white squares) projects. Magenta lines are isolines of mean sea surface height corresponding to the main Antarctic Circumpolar Current (ACC) fronts: Subantarctic Front (SAF; $-9 \mathrm{~cm})$, Polar Front (PF; $-43 \mathrm{~cm}$ ) and Southern ACC Front (SACCF; $-105 \mathrm{~cm}$ ). Volume transports were computed across the blue, red and green sections (labelled S1, S2 and S3). Background is bottom topography. Black contours correspond to the following isobaths: 5000, 3000, 1500, 1000 and $300 \mathrm{~m}$. A few topography features are indicated: East of Burwood Banks (EBB), Shag Rocks Passage (SRP), Shackleton Fracture Zone (SFZ), West Scotia Ridge (WSR), South Scotia Ridge (SSR), Phoenix Antarctic Ridge (PAR), Terror Rise (TR), Quest Fracture Zone (QFZ), Endurance Fracture Zone (EFZ), Ona Rise (OR), Ona Seafloor Depression (OSD) and Northeast Scotia Sea Basin (NESSB). Insert in the upper left corner shows the Southern Ocean bathymetry and a schematic representation of the Antarctic Circumpolar Current. Dashed black rectangle corresponds to the area of interest. 
lite altimetric data (Koenig et al., 2014). Over 20 years, the volume transport in the upper $3000 \mathrm{~m}$ had a mean of $140 \mathrm{~Sv}( \pm 2.2 \mathrm{~Sv})$, a standard deviation of $10 \mathrm{~Sv}$, and a range of $79 \mathrm{~Sv}$. The volume transport was tentatively extended to the bottom providing a full-depth total transport of $141 \mathrm{~Sv}( \pm 2.7 \mathrm{~Sv})$. The small transport values below $3000 \mathrm{~m}$ were attributed to the hypothesis that the deep local circulation cells in the two semi-closed basins of the Yaghan and Ona Basins have a close to zero net transport as the westward and eastward flow components tend to cancel out. Yearly means varied from 133.6 Sv in 2011 to $150 \mathrm{~Sv}$ in 1993 and standard deviations (stds) from 8.8 Sv in 2009 to $17.9 \mathrm{~Sv}$ in 1995. Therefore, the altimetry-derived transport time series puts the canonical ISOS values, a mean of $133.8 \mathrm{~Sv}$ and a std of $11.2 \mathrm{~Sv}$ as obtained from a year-long record in 1979 (Whitworth, 1983; Whitworth and Peterson, 1985), in context as a low transport year.

Near-bottom velocities in DP acquired within the cDrake experiment (2007-2011) (Fig. 1) revealed large near-bottom velocities not aligned with the surface flow and with year-long means in excess of $0.10 \mathrm{~m} \mathrm{~s}^{-1}$ (Chereskin et al., 2009, 2012). The travel time measurements from the C-PIES of the cDrake high-resolution array provided a full-depth ACC baroclinic transport relative to the bottom of $127.7 \pm 5.9 \mathrm{~Sv}$ with a standard deviation of $8.1 \mathrm{~Sv}$ over 4 years (Chidichimo et al., 2014). The mean barotropic transport estimated from the near-bottom current meter records, was $45.6 \mathrm{~Sv}$ with an uncertainty of $8.9 \mathrm{~Sv}$, leading to a mean total transport of $173.3 \pm 10.7$ Sv (Donohue et al., 2016 ). A similarly large mean total transport estimate of $175 \mathrm{~Sv}$ through DP was obtained combining Argo float displacements and historical hydrography from the World Ocean Atlas 2009 to determine a global mass conserving mean circulation with $1^{\circ}$ resolution grid (Colin de Verdière and Ollitrault, 2016).

General circulation models assimilating satellite altimetric and hydrographic data provide dynamically consistent ocean state estimates. The Southern Ocean State Estimate (SOSE) with a $1 / 6^{\circ}$ horizontal resolution and 42 vertical levels led to a mean total transport estimate over 6 years (2005-2010) of $149 \mathrm{~Sv}$ at Drake Passage (Peña-Molino et al., 2014). Nine ocean reanalyses were recently intercompared in the Southern Ocean as part of the polar ocean reanalysis intercomparison project (Uotila et al., 2019). They had an ensemble mean volume transport of $152 \pm 19 \mathrm{~Sv}$ through DP. The horizontal resolution of the reanalyses ranged from $1^{\circ}$ to $14^{\circ}$. The low resolution reanalyses provided larger mean transports than the eddy-permitting reanalyses. This is consistent with Farneti et al. (2015) who found that a better representation of ocean eddies resulted in lower ACC volume transport.

The objective of this paper is to examine the total volume transport at Drake Passage in a state-of-the-art high-resolution $\left(1 / 12^{\circ}\right)$ reanalysis, the 25-year-long GLORYS12 reanalysis from Mercator Ocean. GLORYS12 reanalysis has been shown to correctly reproduce the hydrography and velocities in the Argentine Basin (Artana et al., 2018a, b). To evaluate the GLORYS12 reanalysis in DP, we compared the daily model outputs with the recent mooring data from the DRAKE and cDrake experiments. The paper is structured as follows: the Mercator Ocean reanalysis, in situ and satellite data are described in Section 2. In Section 3, we compare model velocities to altimetry-derived velocities and to moorings time series (not assimilated in the system). In Section 4, we examine the reanalysis total volume transport across three sections in Drake Passage. Finally, Section 5 summarizes and concludes.

\section{Model output and data}

\subsection{Mercator Ocean global reanalysis}

We used daily means of 25 years (1993-2017) of highresolution $\left(1 / 12^{\circ}\right)$ global Mercator Ocean reanalysis GLORYS12 from Copernicus Marine Environment Monitoring Service (CMEMS, http://marine.copernicus.eu/). GLORYS12 is based on the current real-time global forecasting CMEMS system (PSY4V3, Lellouche et al., 2018). The model has 50 vertical levels with 22 levels in the upper $100 \mathrm{~m}$ leading to a vertical resolution of $1 \mathrm{~m}$ in the upper levels and $450 \mathrm{~m}$ near the bottom. The physical component of the model is the Nucleus for European Modeling of the Ocean (NEMO) platform (Madec et al., 2008). The model is driven at the surface by the European Center for Medium-Range Weather Forecasts ERAinterim atmospheric reanalysis. A 3-h sampling of atmospheric quantities (temperature, humidity and wind) is used to reproduce the diurnal cycle. Downward longwave and shortwave radiative fluxes and rainfall (solid + liquid) fluxes are also used in the surface heat and freshwater budgets at daily frequency. An analytical formulation (Bernie et al., 2005) is applied to the shortwave flux in order to reproduce an ideal diurnal cycle. Observations are assimilated by means of a reduced-order Kalman filter with a 3-D multivariate modal decomposition of the background error and a 7-day assimilation cycle (Lellouche et al., 2013). Along-track sea level anomaly (SLA) from satellite altimetric data from CMEMS (Pujol et al., 2016), AVHRR satellite sea surface temperature (SST) from NOAA, Ifremer/CERSAT sea-ice concentration (Ezraty et al., 2007), and in situ temperature and salinity vertical profiles from the latest CORA in situ databases (Cabanes et al., 2013; Szekely et al., 2016) are jointly assimilated. A "hybrid" Mean Dynamic Topography (MDT) has been also used as a reference for altimetric data assimilation. This hybrid MDT is based roughly on the CNES-CLS13 MDT (Rio et al., 2014) with adjustments made using a Mercator Ocean global reanalysis at $14^{\circ}$, a geoid model based on GRACE and GOCE data and an improved post glacial rebound (also called glacial isostatic adjustment). The MDT is a very important component in the analysis system because it makes assimilation of altimetry data possible 
and indirectly constrains the mean circulation of the model. Moreover, a 3D-VAR scheme provides a 3-D correction for the slowly evolving large-scale biases in temperature and salinity when enough observations are available (Lellouche et al., 2018).

\subsection{Satellite altimetry data}

GLORYS12 reanalysis assimilates along-track SLA from CMEMS (Pujol et al., 2016). An example of the model realization in terms of SLA data assimilation is shown along-track \#104 where the DRAKE moorings were installed (Fig. 2). The GLORYS12 and satellite along-track SLA time series are similar (Fig. 2a and b), with differences (Fig. 2c) accounting for the data and model uncertainties (instrumental, MDT or representativeness errors, Lellouche et al., 2018). The differences between the model and altimetric SLA do not show any temporal trend nor significant interannual variations.

We used the DUACS delayed time altimeter gridded products produced as part of the CMEMS (Pujol et al.,
2016) for comparisons. The gridded product includes data from all available altimeters at any given time and comprises maps of surface-geostrophic velocities and their anomalies with a spatial resolution of $14^{\circ}$ on a Mercator regular grid and a daily sampling.

\subsection{In situ data}

Two types of in situ data are distinguished: the ocean data that are assimilated (mainly hydrographic data from hydrographic sections, Argo floats, XBT...) and ocean data that are not assimilated such as current velocity measurements. Comparisons with assimilated data showed a good performance indicating a correct assimilation (not shown). We focus on the comparison with independent velocity data (not assimilated) from two intensive measurement data sets, the DRAKE and the cDrake data sets.

The DRAKE current-meter array, made up of nine moorings (M1 through M10, M8 being lost), was located under the Jason altimeter track \#104, parallel to and downstream of the SFZ (Fig. 1, white dots). These moorings
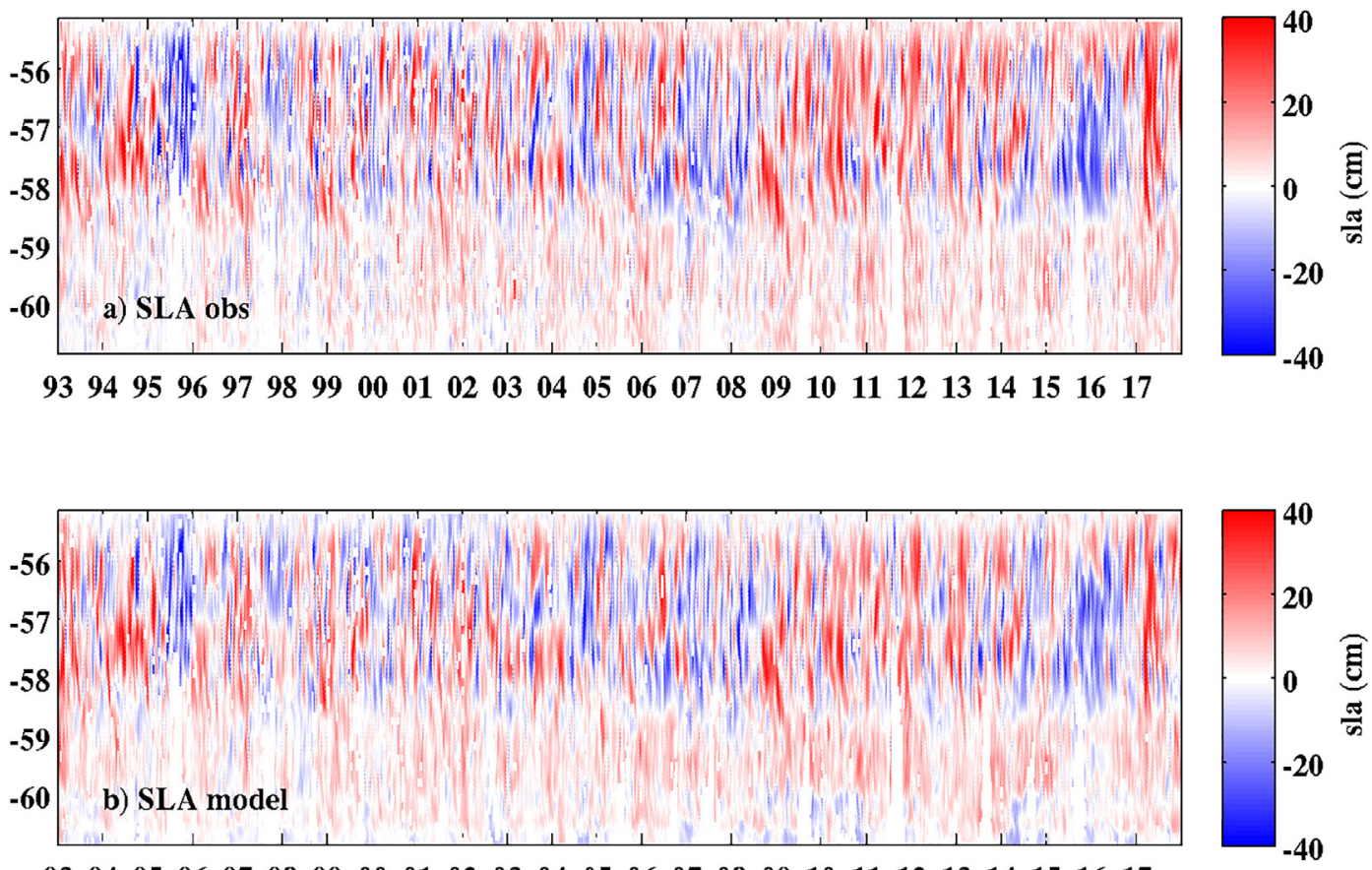

$\begin{array}{lllllllllllllllllllllllll}93 & 95 & 96 & 97 & 98 & 99 & 00 & 01 & 02 & 03 & 04 & 05 & 06 & 07 & 08 & 09 & 10 & 11 & 12 & 13 & 14 & 15 & 16 & 17\end{array}$

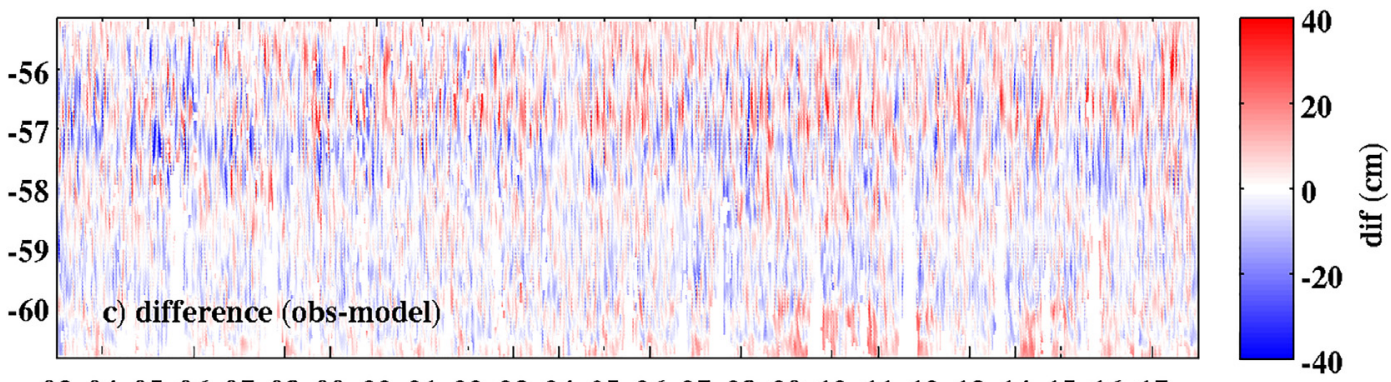

$\begin{array}{lllllllllllllllllllllllll}93 & 94 & 95 & 97 & 98 & 99 & 00 & 01 & 02 & 03 & 04 & 05 & 06 & 07 & 08 & 09 & 10 & 11 & 12 & 13 & 14 & 15 & 16 & 17\end{array}$

Fig. 2. Times series (10-day resolution) of sea level anomaly (in $\mathrm{cm}$ ) along-track \#104 over the 25 years: (a) SLA observations from satellite altimetry (CMEMS along-track product). (b) GLORYS12 SLA. (c) Difference between observations and GLORYS12. 
gathered 3 years (2006-2009) of velocity measurements from vector averaging current-meters (VACM) in the Yaghan Basin (Ferrari et al., 2012) and 2 years (20062008) in the Ona Basin (Ferrari et al., 2013). An Acoustic Doppler Current Profiler (ADCP) settled in the uppermost subsurface buoy at M1 and M3 provided velocity time series in the upper $350 \mathrm{~m}$ of the water column (Koenig et al., 2014).

The cDrake data set comprises time series from currentand pressure-recording inverted echo sounders (CPIES) over 4 years, from November 2007 to November 2011 (e.g. Chereskin et al., 2009). The array of CPIES consisted of a transport line of 20 CPIES spanning $800 \mathrm{~km}$ across DP (called the C-Line), and a local dynamic array (LDA) of 21 $(7 \times 3)$ CPIES (Fig. 1, white squares). The near-bottom current-meters of the CPIES were located at $50 \mathrm{~m}$ above the seafloor. Three current-meter moorings were added on the continental slopes, two (M1 and M2) off Tierra de Fuego and one (M3) off the Antarctic Peninsula (Fig. 1) (e.g. Tracey et al., 2015; Chereskin et al., 2012).

\subsection{SAM and ENSO index}

We used the Southern Annular Mode (SAM) index and ENSO index (Niño 3.4) to examine potential coherences between ACC transport variations and large-scale climate indices. Positive values of the SAM index indicate poleward intensification of the Southern Hemisphere westerlies. The Niño 3.4 anomalies represent the average equatorial SSTs across the equatorial Pacific between $5 \mathrm{~N}$ and $5 \mathrm{~S}$, 170-120W. El Niño or La Niña events are defined when the Niño 3.4 SSTs exceed $\pm 0.4{ }^{\circ} \mathrm{C}$ for a period of six months or more. The SAM and ENSO (Niño3.4) time series were downloaded from https://climatedataguide. ucar.edu/climate-data/marshall-southern-annular-mode-samindex-station-based and https://www.cpc.ncep.noaa.gov/ data/. The trend in each of these time series has previously been removed before performing any analysis.

\section{Assessment of GLORYS12 velocities in Drake Passage}

\subsection{Surface geostrophic velocities: means and variations}

The ACC consists of a number of circumpolar fronts, which correspond to water mass boundaries and to deepreaching jets (e.g. Orsi et al., 1995). Sokolov and Rintoul (2009) showed that the principal ACC fronts comprised multiple branches along the path of the ACC and that they tend to converge into the three main jets (from north to south, the Subantarctic Front, the Polar Front and the Southern ACC front) as they enter DP. Velocities are large in the jet cores $\left(>50 \mathrm{~cm} \mathrm{~s}^{-1}\right)$ (e.g., Nowlin et al., 1977; Provost et al., 2011).

As expected, the mean surface geostrophic velocities (derived from the model MDT) have a similar structure to those derived from the CNES-CLS13 MDT, with a convergence of the frontal systems mostly confined in the northern part of DP due to the topographic constraint of the Phoenix Antarctic Ridge (PAR), the Shackleton Fracture Zone (SFZ) and West Scotia Ridge (WSR) (Figs. 1 and 3a). This resemblance is not surprising as the model MDT is roughly based on the CNES-CLS13 MDT. At some locations (e.g., on the South American continental slope and on the West Scotia Ridge) GLORYS12 mean surface geostrophic velocities are larger than altimetry-derived velocities by $+10 \mathrm{~cm} / \mathrm{s}$.

Model surface eddy kinetic energy (EKE) shows the same patterns as that derived from altimetry with values larger than $500 \mathrm{~cm}^{2} \mathrm{~s}^{-2}$ in the northern part of DP, and in excess of $1000 \mathrm{~cm}^{2} \mathrm{~s}^{-2}$ over the northern Scotia Sea downstream of the Yaghan Basin (Fig. 3c). GLORYS12 EKE is generally larger than the altimetry-derived EKE, with differences of the order of $200 \mathrm{~cm}^{2} \mathrm{~s}^{-2}$ over rough topography (Fig. 3d): in the central DP over the West Scotia Ridge (WSR), over the Quest and Endurance fracture zones (QFZ and EFZ) and in the south over isolated topographic features such as Terror Rise (TR) (compare Fig. 3d and Fig. 1).

\subsection{Comparisons during DRAKE and cDrake experiments}

GLORYS12 velocities were co-located in space and time with the daily averaged current-meter velocities. Comparisons with the DRAKE velocity data in the water column, with altimetry-derived surface velocities during the DRAKE experiment and with the cDrake velocity data near the seafloor are summarized in Figs. 4 and 5, Tables $1 \mathrm{a}$ and $1 \mathrm{~b}$ in the appendix (for DRAKE), Tables $2 \mathrm{a}$ and $2 \mathrm{~b}$ in the appendix (for the gridded altimetry derived velocities), Fig. 6 and Tables $3 a$ and $3 b$ in the appendix (for cDrake).

\subsubsection{Water column: comparison with DRAKE data}

Comparisons in the Yaghan Basin (moorings M1, M2, M3, M4, M5 from DRAKE), are made separately for the first measurement period (2006-2008) (M2 was lost) (Fig. 4a northern part of the section for the VACMs; Fig. 4d for the ADCPs, and Table 1a from the Appendix) and the second period (2008-2009) (Fig. 4b for the VACMs; Fig. 4e for the ADCPs, and Table $1 \mathrm{~b}$ from the Appendix). Comparisons for the Ona Basin only cover 2006-2008 (Fig. 4a southern part of the section; Table 1a from the Appendix).

In general, the amplitude of the mean velocity vector difference between observations and GLORYS12 is small $\left(<2 \mathrm{~cm} \mathrm{~s}^{-1}\right.$ over all instruments, on average) (Fig. 4, Tables $1 \mathrm{a}$ and $1 \mathrm{~b}$ from the Appendix third column). Overall, there is no sign bias (Tables 1a and $1 \mathrm{~b}$ from the Appendix, third column).

The largest amplitude and direction of the mean velocity difference is found at M9 $\left(\sim 6 \mathrm{~cm} \mathrm{~s}^{-1}\right.$ at 1000 and $\left.2500 \mathrm{~m}\right)$ and results from a too small mean along-track component in GLORYS12, the mean cross-track velocity components being the same in the in situ data and in GLORYS12 

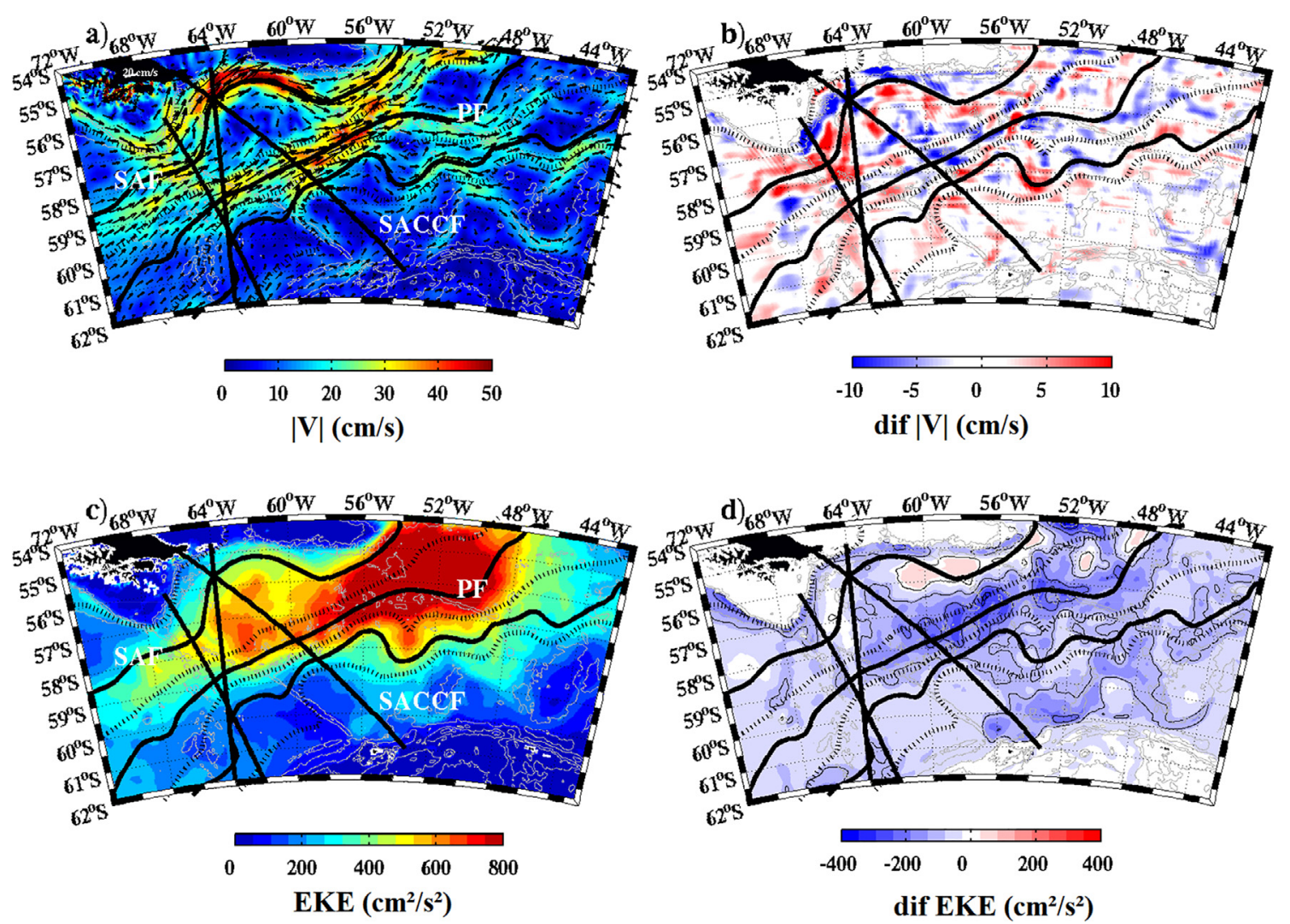

Fig. 3. (a) Mean surface velocity magnitude (in $\mathrm{cm} / \mathrm{s}$ ) and mean surface velocity vectors (when larger than $10 \mathrm{~cm} / \mathrm{s}$ ) from GLORYS12 MDT. (b) Differences between the mean surface velocity magnitudes from CNES-CLS13 MDT and GLORYS12 MDT. (c) Mean eddy kinetic energy per unit mass (in $\mathrm{cm}^{2} / \mathrm{s}^{2}$ ) from 25 years of GLORYS12. (d) Differences between the Eddy Kinetic Energy from satellite altimetry and GLORYS12. Black contours are isolines of mean sea surface height corresponding to the main Antarctic Circumpolar Current (ACC) fronts: from north to south the Subantarctic Front (SAF; $-9 \mathrm{~cm})$, the Polar Front (PF; $-43 \mathrm{~cm})$ and the Southern ACC Front (SACCF; $-105 \mathrm{~cm})$. The black lines indicate the position of the 3 sections where ACC transport was computed.

$\left(\sim+2 \mathrm{~cm} \mathrm{~s}^{-1}\right)$. The mean cross-track velocity components of GLORYS12 compare well with the in situ data as seen in Fig. 5a and c. The mean cross-track velocities along the DRAKE section from GLORYS12 provide insight on the locations of the moorings with respect to the mean jet velocities and counter-flows (Fig. 5a and c). GLORYS12 mean cross-track velocity section shows fours bands of bottom-reaching eastward flow (Fig. 5a). Those bands match observations and correspond to the SAF (north of $56^{\circ} \mathrm{S}$ ), the PF (around $57.5^{\circ} \mathrm{S}$ ) and two branches for the SACCF: SACCF-N at $58.5^{\circ} \mathrm{S}$ and SACCF-S at $60^{\circ} \mathrm{S}$, as the SACCF branches when crossing the SFZ (Provost et al., 2011). Westward deep velocities in the center of the Yaghan Basin near $57^{\circ} \mathrm{S}$ match the deep recirculation observed in Ferrari et al. (2012). GLORYS12 mean cross-track velocity section compare rather well with the reconstructed mean flow obtained using the current-meter data, altimetric data and a look up table in Koenig et al. (2014) (their Fig. 11a).

The direction of the mean velocity vectors in the model follows the observations. GLORYS12 mean vector velocity vectors rotate with depth (Fig. $4 \mathrm{a}$ and $\mathrm{b}$ ) as in the observations (Ferrari et al., 2014, their Fig. 5). A rotation of the velocity vector suggests an upwelling or downwelling depending on the sense of the rotation: a clockwise rotation for downwelling, and a counterclockwise rotation for upwelling in the Southern Hemisphere (e.g. Ferrari et al., 2014). Therefore, both GLORYS12 and the observations suggest a mean downwelling at M3, M4, M6 and M9 and a mean upwelling at M5 (Fig. 4a and b). On the northern continental slope (M1, M2), the direction of the mean velocity vectors does not change with depth neither in the observations nor in the reanalysis.

Variance ellipses of the reanalysis velocity are of the same order of magnitude as in the observations (Fig. 4a, $\mathrm{b}, \mathrm{d}$ and e). The largest variance ellipses of the velocity differences (axes of the order of $5 \mathrm{~cm} \mathrm{~s}^{-1}$ ) are found on the northern continental slope off Tierra de Fuego where reanalysis underestimates velocity variance (Tables 1a and $1 \mathrm{~b}$ from the Appendix). The std of GLORYS12 cross-track velocity along the DRAKE section shows large values above $1500 \mathrm{~m}$ in rather good agreement with the observations (apart from the underestimation by about $5 \mathrm{~cm} \mathrm{~s}^{-1}$ over the northern continental slope) (Fig. 5b and d). The GLORYS12 cross-track velocity stds compare rather well with the reconstructed ones using the currentmeter data, altimetric data and the look up table method (Koenig et al., 2014; their Fig. 11b). GLORYS12 std 

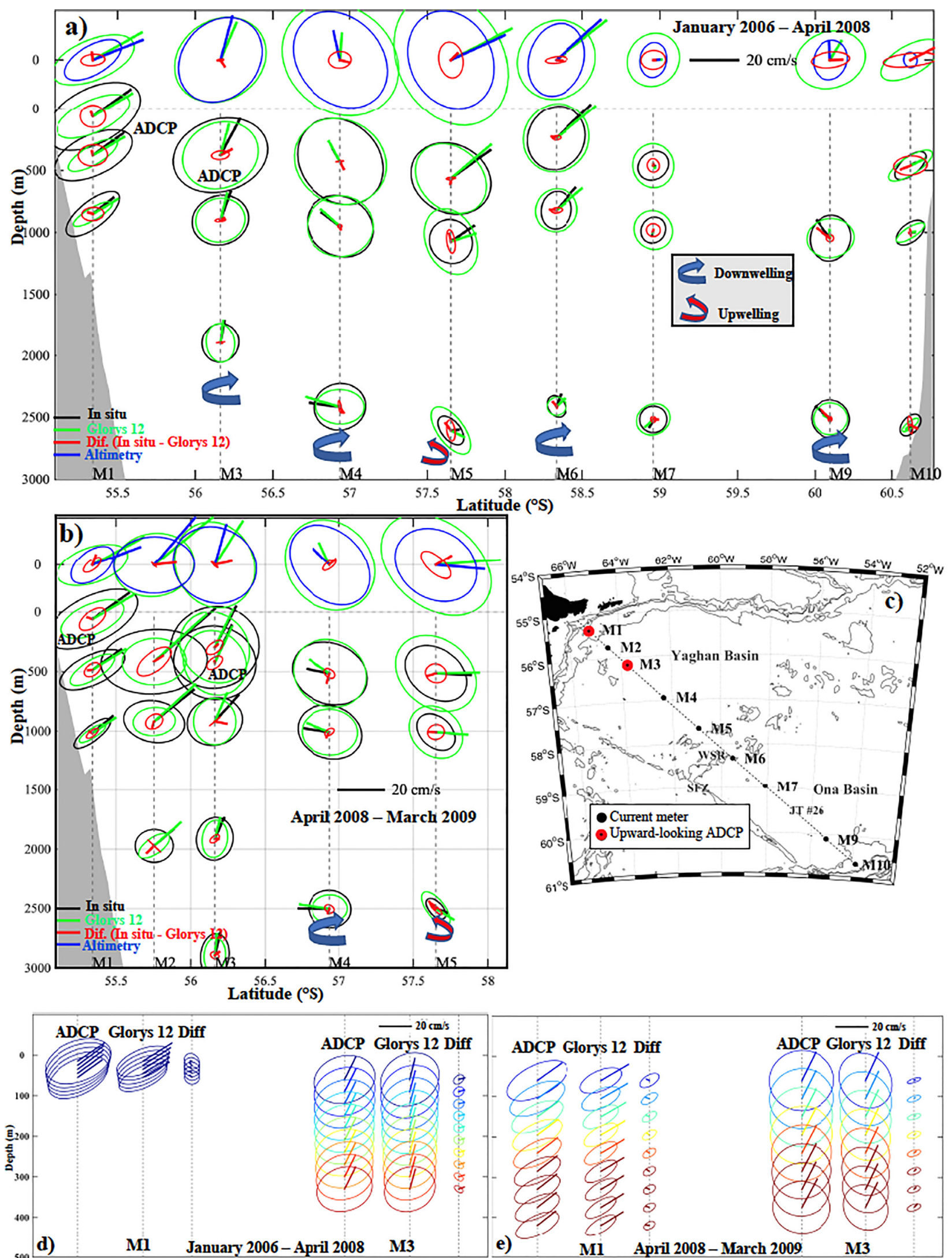
decreases from the surface down to a minimum around $2000 \mathrm{~m}$ and increases below $3000 \mathrm{~m}$, depths that were not sampled with the DRAKE current meters.

Correlations between the cross-track velocity time series from observations and the model are almost always highly significant ( $r>0.5$ above 99\% confidence level) (Tables 1a and $1 \mathrm{~b}$ from the Appendix) except for the two southernmost moorings M9 and M10 which are located in a rather quiet region.

\subsubsection{Surface: comparison with altimetry-derived velocities during the DRAKE experiment}

Amplitude and direction of the mean surface velocities in GLORYS12 show a general consistent agreement with altimetry-derived velocities during the DRAKE experiment period (differences $<4 \mathrm{~cm} \mathrm{~s}^{-1}$ on average, Tables $2 \mathrm{a}$ and $2 \mathrm{~b}$ from the Appendix and Fig. 4a and b), as already noticed for the 25 years (Fig. 3b). Surface velocity variance ellipses are larger for GLORYS12 than for altimetry during the DRAKE years (differences in the axes of the order of $5 \mathrm{~cm} \mathrm{~s}^{-1}$, Fig. $4 \mathrm{a}$ and $\mathrm{b}$ and Tables $2 \mathrm{a}$ and $2 \mathrm{~b}$ ), as observed in the EKE difference during the 25 years (Fig. 3d). Surface velocity component time series (GLORYS12 and altimetryderived) are correlated ( $\mathrm{r}>0.5$, significant at 95\%) at all current meter mooring locations except for the southernmost one M10 (Tables 3a and 3b from the Appendix).

\subsubsection{Near the seafloor: comparison to cDrake current- meters}

As shown in Chereskin et al. (2009), mean velocities in excess of $10 \mathrm{~cm} \mathrm{~s}^{-1}$ at $50 \mathrm{~m}$ above the seafloor are found at 9 out of the 38 C-PIES sites and major variance ellipse axes larger than $10 \mathrm{~cm} \mathrm{~s}^{-1}$ are commonly observed (Fig. 6a, Table 3a from the Appendix). The model features similar orders of magnitude for the mean and the variances. The differences in the mean velocities are either very small ( $<2 \mathrm{~cm} \mathrm{~s}^{-1}$ at 23 sites, and $<1 \mathrm{~cm} \mathrm{~s}^{-1}$ at 14 sites) or they are oriented in such a way that they do not contribute to an eastward mean flow (Fig. 6b, Table 3a from the Appendix). Variance ellipses of the difference between observational and model velocities are small (Fig. 6b, Table 3a from the Appendix). Such a good agreement at depth in velocity means and standard deviations in this rough bottom topography environment is surprising as the last layer of the model is several hundreds of meters thick. Half of the correlations between the model and observed velocity time series are significant $(\mathrm{r} \sim 0.4$ above 99\% confidence level, Table 3 last column).

Comparison with the cDrake current meter moorings on the continental slope (M1, M2 off Tierra de Fuego and M3 off the Antarctic Peninsula) also provides small differences in mean values and variance ellipses (inserts in Fig. 6, Table 3b). Most correlations between the model and observed time series are significant $(\mathrm{r} \sim 0.35$ above $99 \%$ confidence level - except for two deep levels).

\subsection{GLORYS12 mean velocities and EKE at different depths and topography}

GLORYS12 mean velocities have been shown to be in good agreement with the current-meter observations. Maps of the mean velocity in the upper levels show a relatively diffuse flow at the entrance to DP concentrating into three jets at the crossing of the PAR, with the SAF along the northern continental slope, the PF to the south above the WSR and the SACCF along the southern continental slope (Fig. 7a and b). The mean SACCF appears made of several thin branches that separate at the crossing of the SFZ and then meander. GLORYS12 confirms the absence of a westward slope current in the South of Drake Passage in agreement with Thompson et al. (2018). At depth, the most salient feature is the deep cyclonic recirculation in the Yaghan Basin as identified in Ferrari et al. (2012) with the DRAKE current-meters. GLORYS121 mean velocities at $4000 \mathrm{~m}$ in this deep gyre exceed $12 \mathrm{~cm} \mathrm{~s}^{-1}$ (Fig. 7h). GLORYS12 deep mean flow at M4 location is westward, in opposite direction to the mean surface flow (Fig. 5).

GLORYS12 mean EKE maps at different depths in Drake Passage show interesting patterns with maxima above sea floor depressions $(>4000 \mathrm{~m})$ with large values $\left(>1000 \mathrm{~cm}^{2} \mathrm{~s}^{-2}\right)$ at the surface that decrease with depth to a minimum of $170 \mathrm{~cm}^{2} \mathrm{~s}^{-2}$ at $2500-3000 \mathrm{~m}$ and then peak up to more than $200 \mathrm{~cm}^{2} \mathrm{~s}^{-2}$ at $3800 \mathrm{~m}$ and below (Fig. 8). The maximum EKE is found at around $52^{\circ} \mathrm{W}$, $55^{\circ} \mathrm{S}$ at all levels, that is just downstream of a topographic bump (less than $3000 \mathrm{~m}$ from the sea surface) north of the EFZ and just south of the East of Burwood Bank Passage. The local EKE maximum observed in the center of the Yaghan Basin $\left(63^{\circ} \mathrm{W}, 55^{\circ} \mathrm{S}\right)$ is reminiscent of the barotropic basin modes with energy at the intra-seasonal time scales described in Koenig et al. (2016). The local maximum at $53^{\circ} \mathrm{W}, 58^{\circ} \mathrm{S}$ over a topographic depression $(>4000 \mathrm{~m})$ to the northwest of the Ona Basin corresponds

Fig. 4. Comparison of GLORYS12 to DRAKE current-meter data and to gridded altimetry-derived velocities at the mooring location. (a) Time-mean velocity vectors and velocity standard deviation ellipses from the current-meters, collocated GLORYS12 outputs, satellite altimetry and the differences in black, green, blue and red respectively from January 2006 to April 2008. (b) Same as (a) from April 2008 to March 2009. (c) Location of the DRAKE current-meter moorings and upward-looking ADCP (black and red dots). Black dotted line corresponds to Jason ground-track \#104. (d) Time-mean velocity vectors and velocity standard deviation ellipses obtained from the ADCP (M1 and M3), collocated GLORYS12 outputs and the differences from January 2006 to April 2008. (e) Same for deployment from April 2008 to March 2009. A clockwise (anticlockwise) rotation of the mean velocity vector with decreasing depth indicates mean downwelling (upwelling). The bottom topography is indicated in solid gray. Velocity scale is indicated in the upper right corner. The y axes in a and $\mathrm{b}$ have 2 zeros, one upper at $-500 \mathrm{~m}$ to make the surface velocity comparison (with altimetry) readable. 

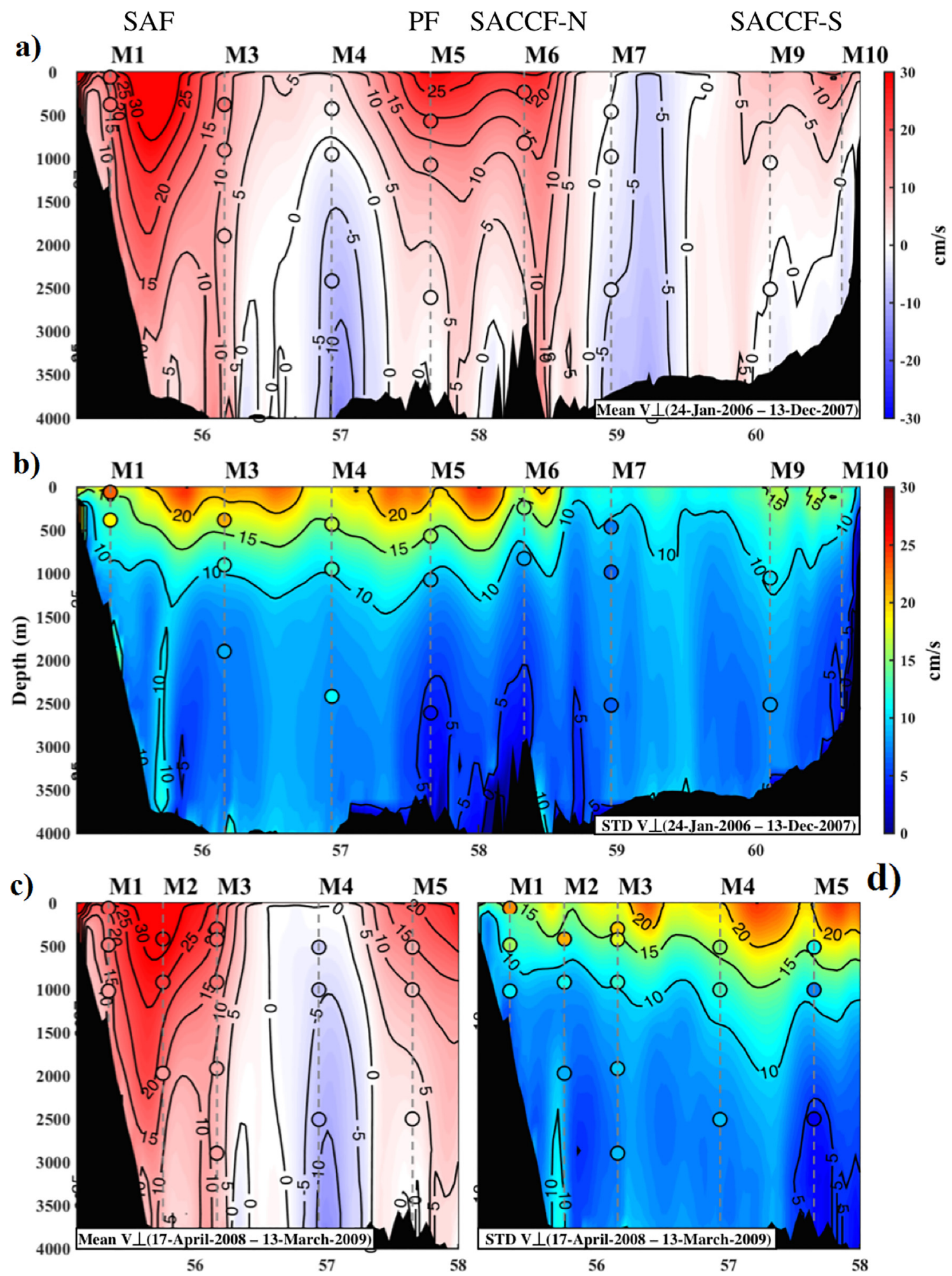

Fig. 5. Mean velocity (a-c) and standard deviation (b-d) across Section 2 (red in Fig. 1) from model outputs for 24 January 2006 to 17 December 2007 and for 17 April 2008 to 13 March 2009. Corresponding values from observations at each instrument are indicated by colored dots. The velocity data were lowpass filtered with a cutoff period of $48 \mathrm{~h}$.

to an intermittent anticyclonic meander of the $\mathrm{PF}$ described in Barré et al. (2008). The EKE maps between 1000 and $3000 \mathrm{~m}$ show local maxima $\left(>100 \mathrm{~cm}^{2} \mathrm{~s}^{-2}\right)$ in/above the valleys between the seamounts forming the West Scotia Ridge $\left(64-53^{\circ} \mathrm{W}, 58-56^{\circ} \mathrm{S}\right)$.

\section{Volume transport across three sections}

Volume transports over the entire water column were computed across three sections: the section used in Bricaud et al. (2018) parallel to and just upstream of the 

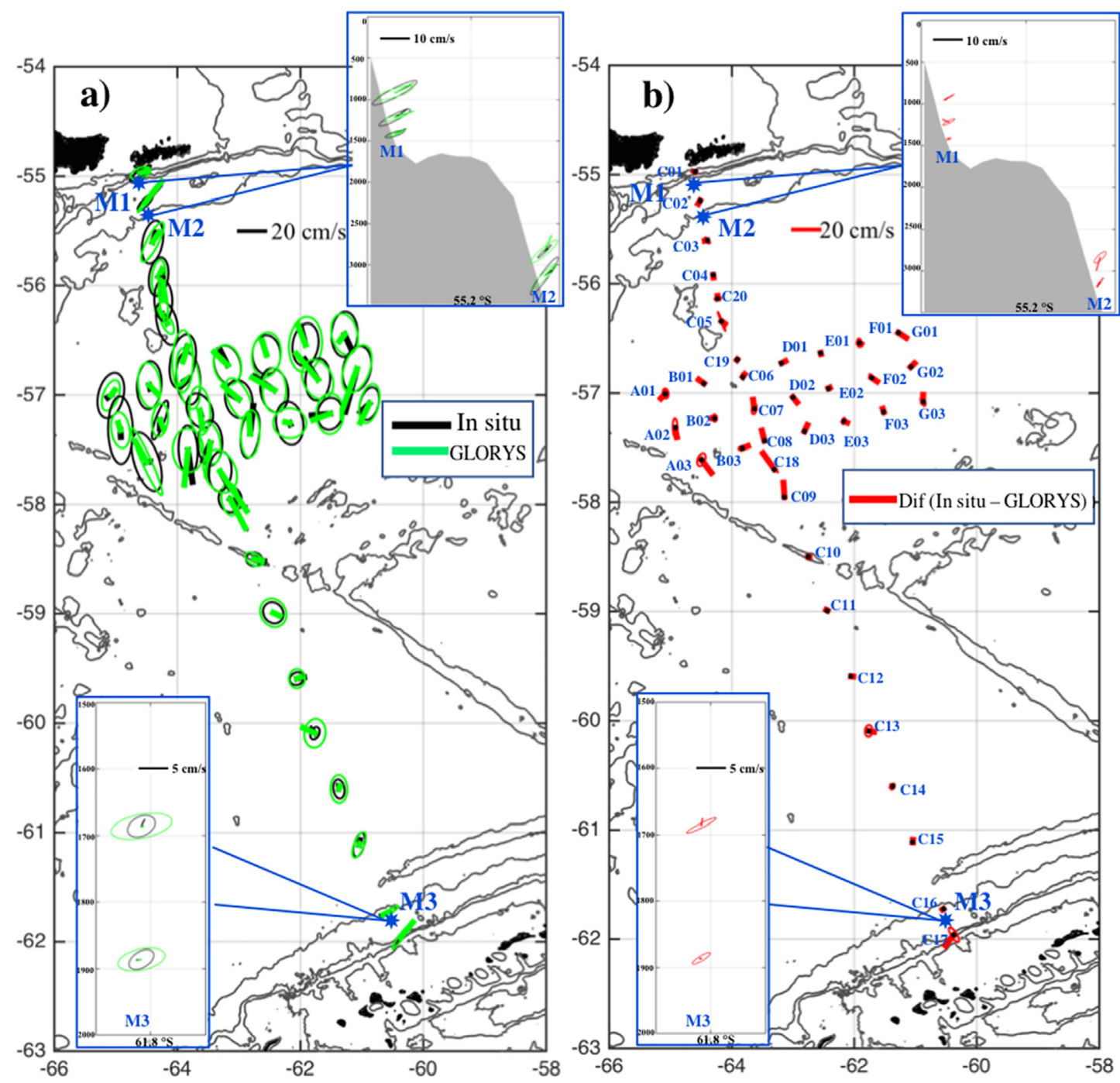

Fig. 6. Comparison of GLORYS12 to cDrake current-meter data (2007-2011). (a) Time-mean velocity vectors and velocity standard deviation ellipses obtained from the 50-m above bottom current-meter measurements and from the current-meter moorings M1, M2 and M3 (in the upper right and bottom left corner) are shown by solid black lines and those from model outputs data by green lines. Locations of the current-meter moorings from cDrake project (M1, M2 and M3) are indicated in blue. (b) Differences are shown in red solid lines. Black contours correspond to the following isobaths: 5000, 3000, 1500, 1000 and $300 \mathrm{~m}$.

cDrake main line (Section 1), the DRAKE section downstream of the SFZ (Section 2) and a meridional section at $64^{\circ} \mathrm{W}$ (Section 3), respectively blue, red and green in Fig. 1.

\subsection{Mean volume transport}

The mean total volume transport over the 25 years (average from the three-time series) of GLORYS12 reanalysis (1993-2017) is $155 \pm 3 \mathrm{~Sv}$. The three transport time series are highly correlated $(r>0.95$ above the $95 \%$ confidence level, at lag 0 ) and the difference in their mean values ( $3 \mathrm{~Sv}$ ) serves at estimating the uncertainty of the mean transport. The small difference in mean values $(<3 \mathrm{~Sv})$ probably comes from interpolation artefacts and boundary effects. Transport from Section 1 is shown in Fig. 9. The daily values range from $128.5 \mathrm{~Sv}$ (September 9, 1996) to 177.3 Sv (April 20, 2015) (Fig. 9a). Although the transport time series do not show any significant long-term trend, they show some low frequency modulation with a minimum in annual mean of $148 \mathrm{~Sv}$ in 2007 (during the DRAKE and cDrake experiments) and a maximum of $160 \mathrm{~Sv}$ in 1993 (Fig. 9b). The years of DRAKE and cDrake experiments show annual mean transport below average (in red Fig. 9b).

\subsection{Spectral content of volume transport time series}

The standard deviations of the transport time series are similar: 6.7, 6.8 and 6.6 Sv for Sections 1, 2 and 3, respectively. The first zero crossing of the autocorrelation function yields an integral time scale of 45 days, giving a large number of degrees of freedom (203) for the 25-year long time series.

The energy conserving spectra show energetic variations at intraseasonal variations with several salient bands of elevated energy (significant at the $95 \%$ confidence level) with 

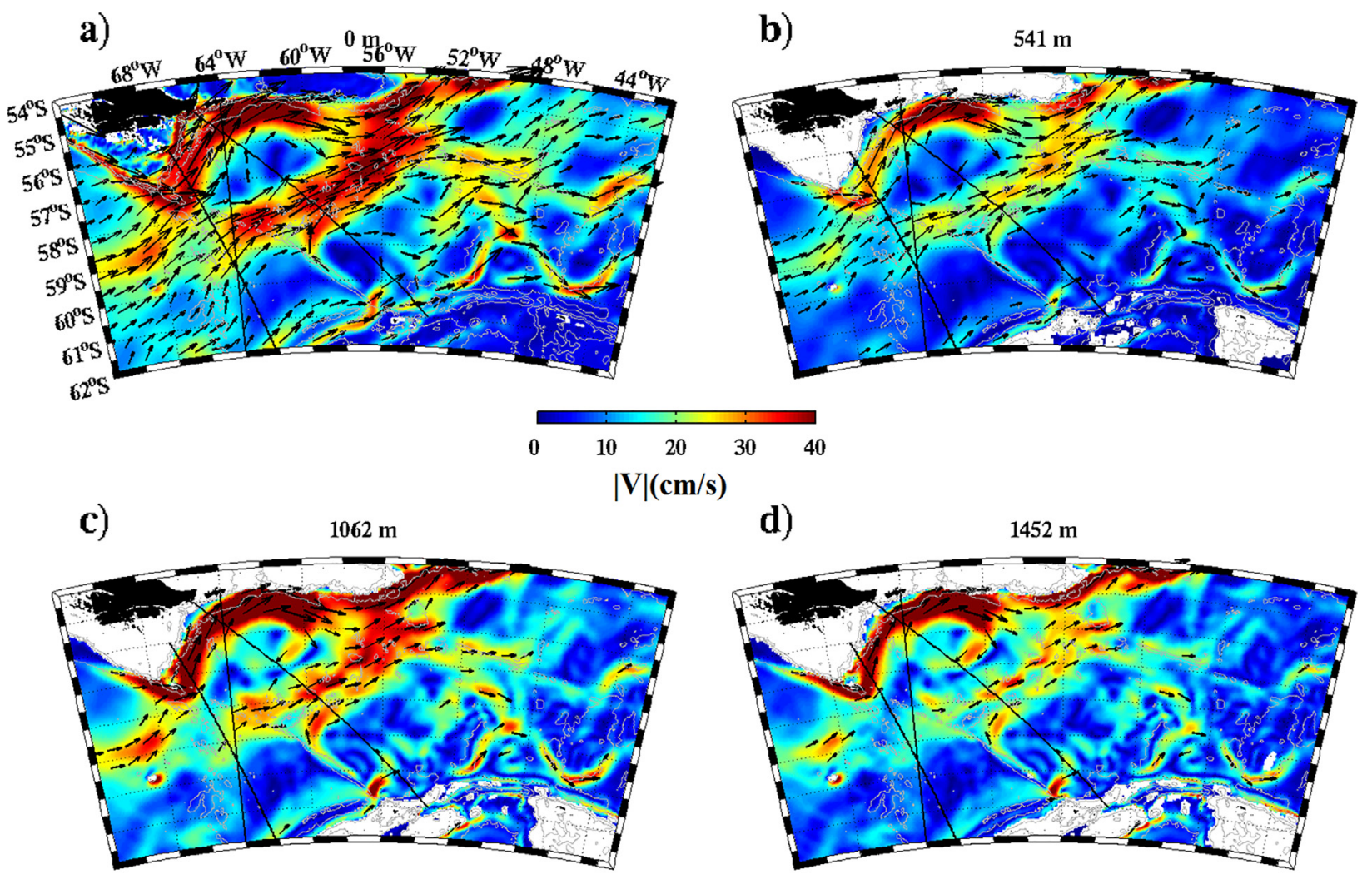

e)

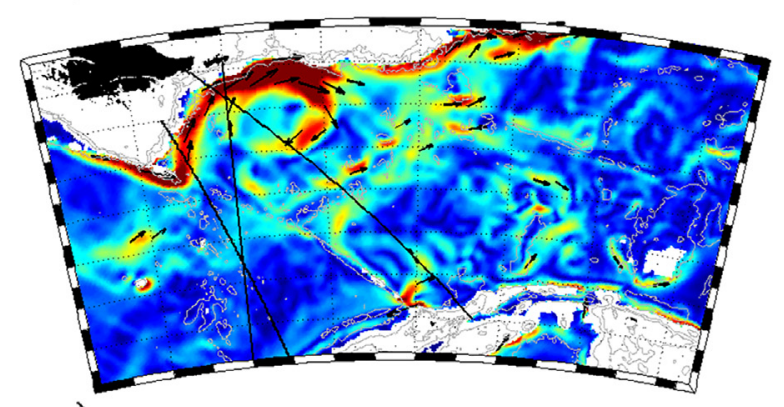

g)

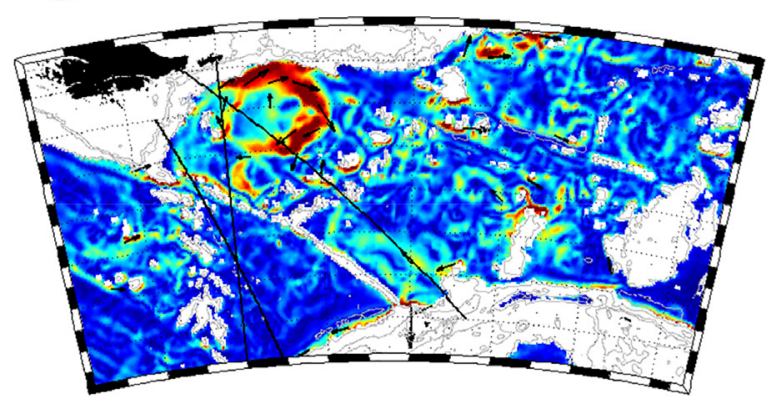

f)

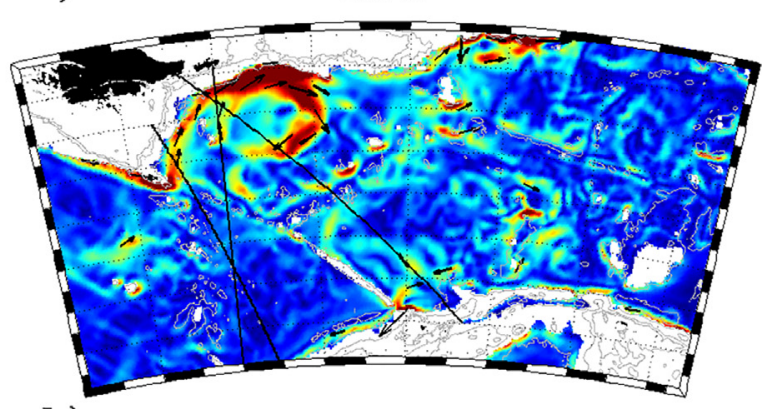

h)

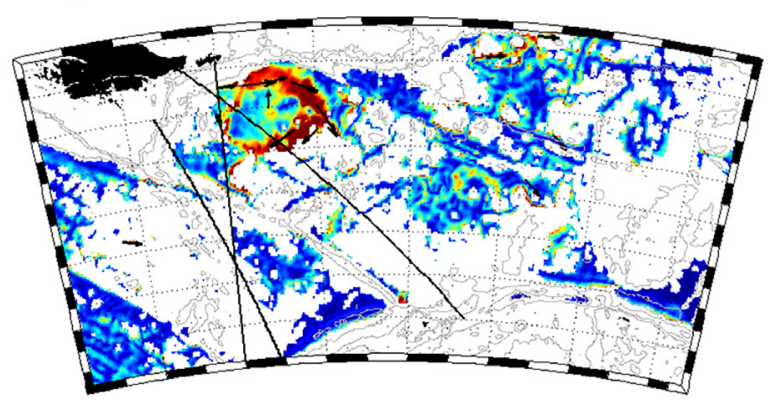

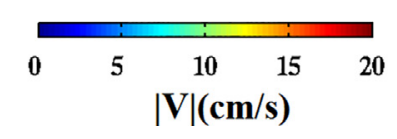

Fig. 7. Mean velocity magnitude (in $\mathrm{cm} / \mathrm{s}$ ) and mean velocity vectors (when larger than $10 \mathrm{~cm} / \mathrm{s}$ in a-b and larger than $5 \mathrm{~cm} / \mathrm{s}$ in $\mathrm{c}-\mathrm{h}$ ) from 25 years of ocean reanalysis (1993-2017) at different model depths. 

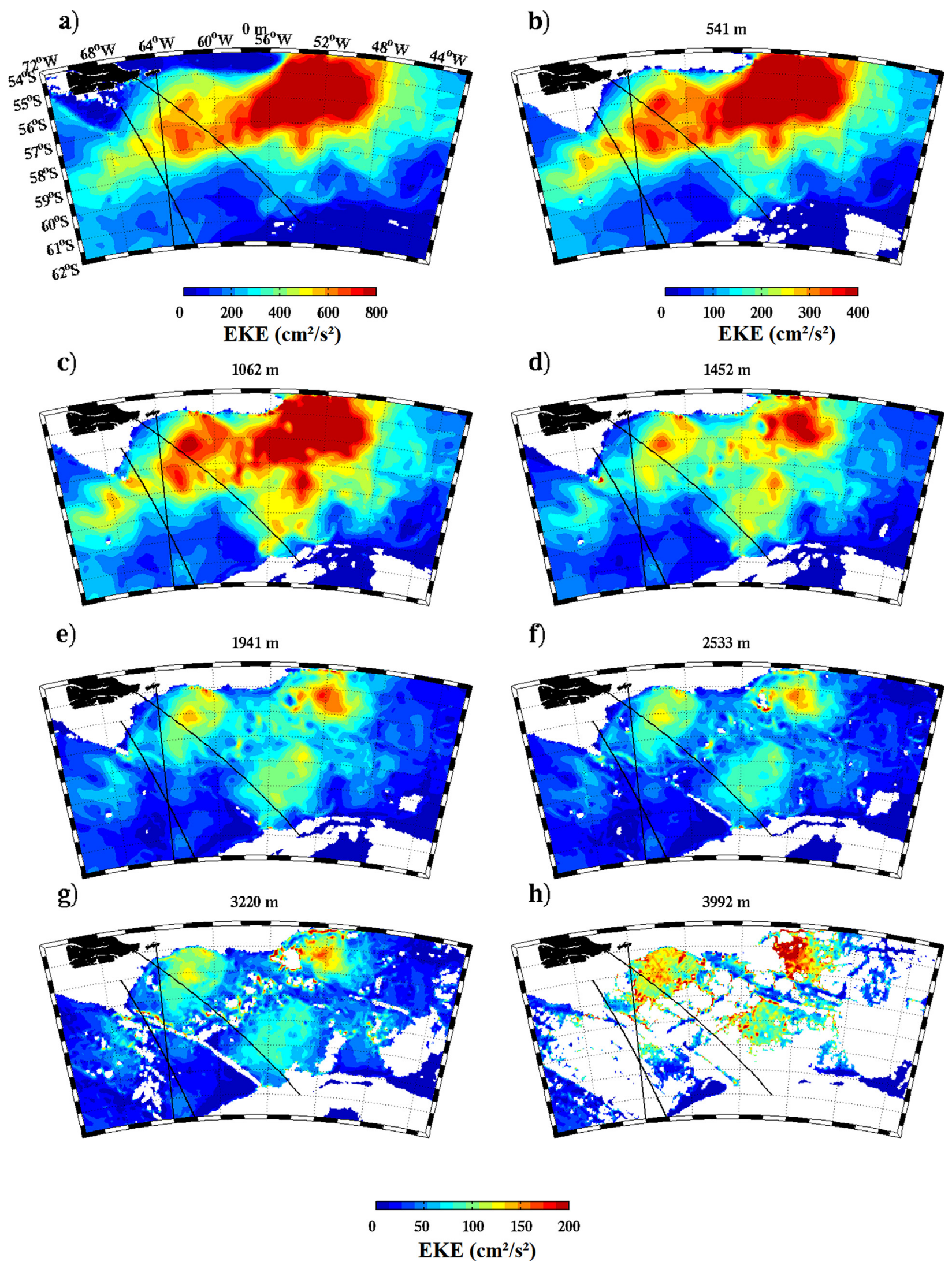

Fig. 8. Eddy Kinetic energy $\left(\right.$ in $\left.\mathrm{cm}^{2} / \mathrm{s}^{2}\right)$ from 25 years of ocean reanalysis (1993-2017) at different model depths. Note that the color scales in a and b are different from those in $\mathrm{c}-\mathrm{h}$. 
a)
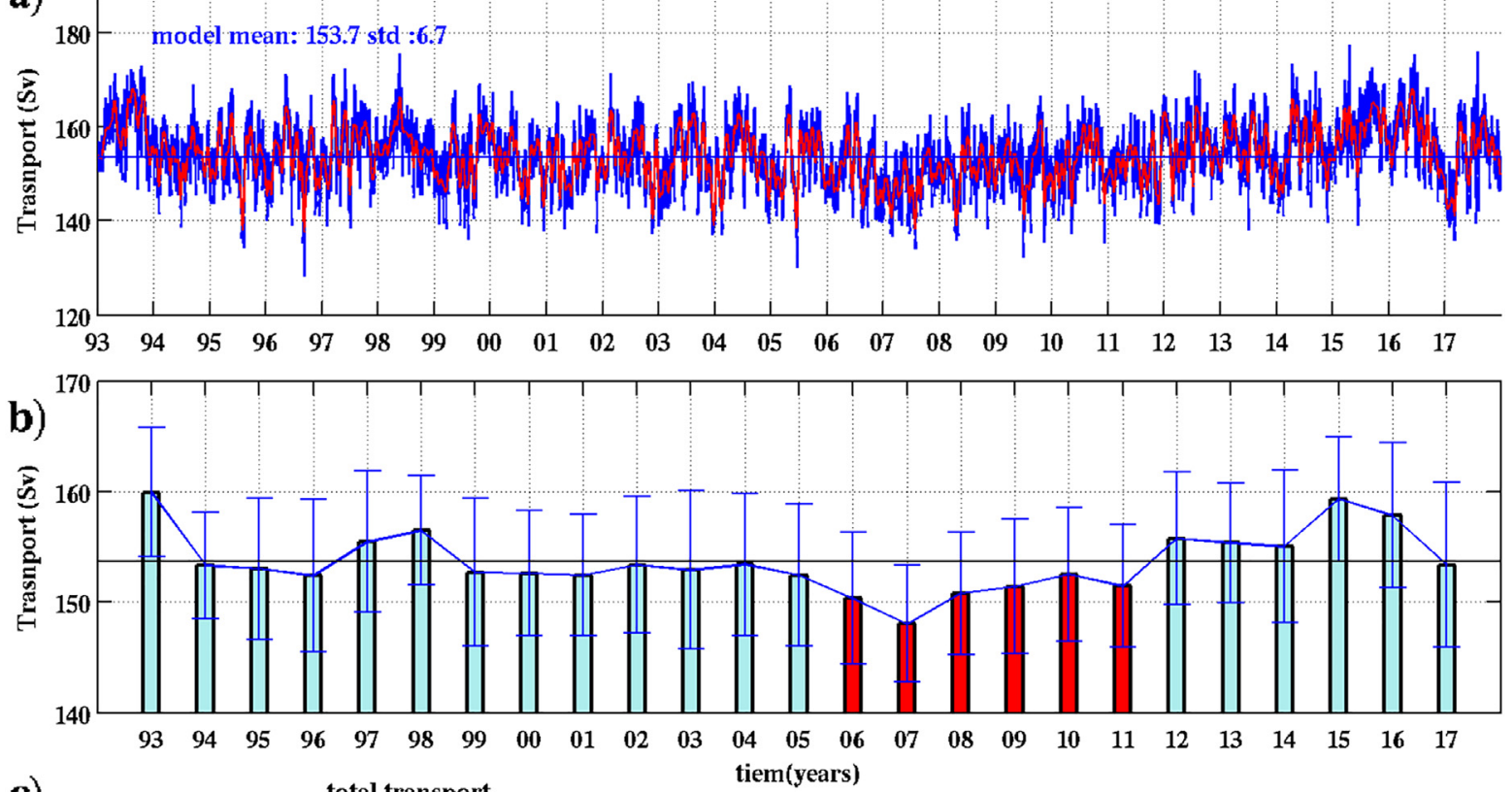

c)

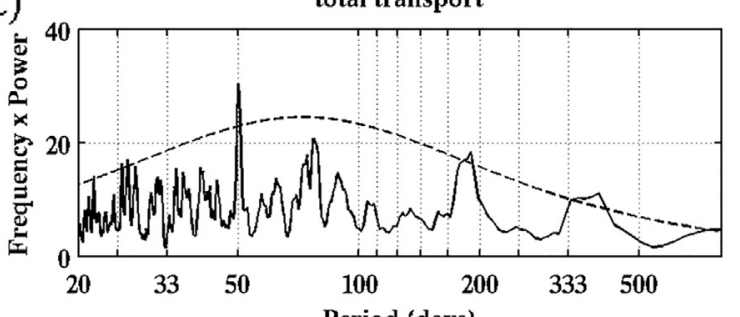

d) $\begin{gathered}\text { Period (days) } \\ \text { total transport }\end{gathered}$
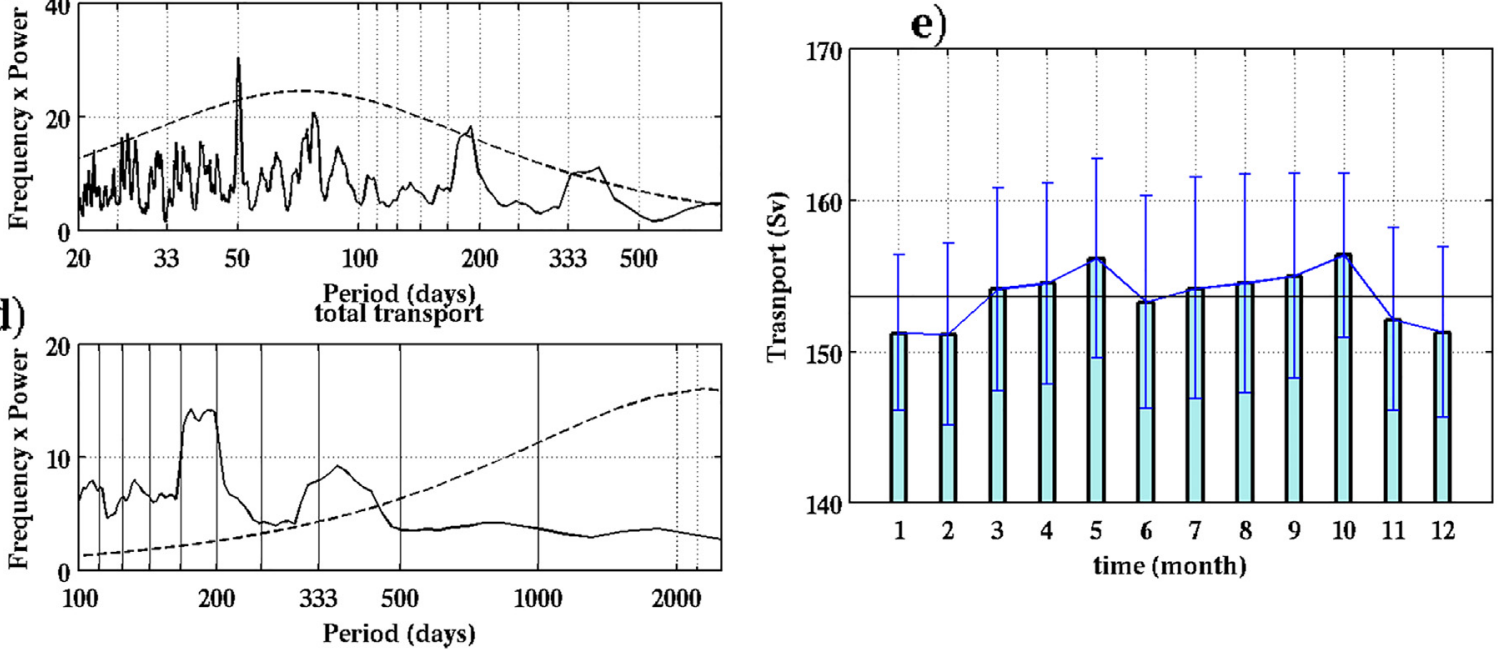

f)
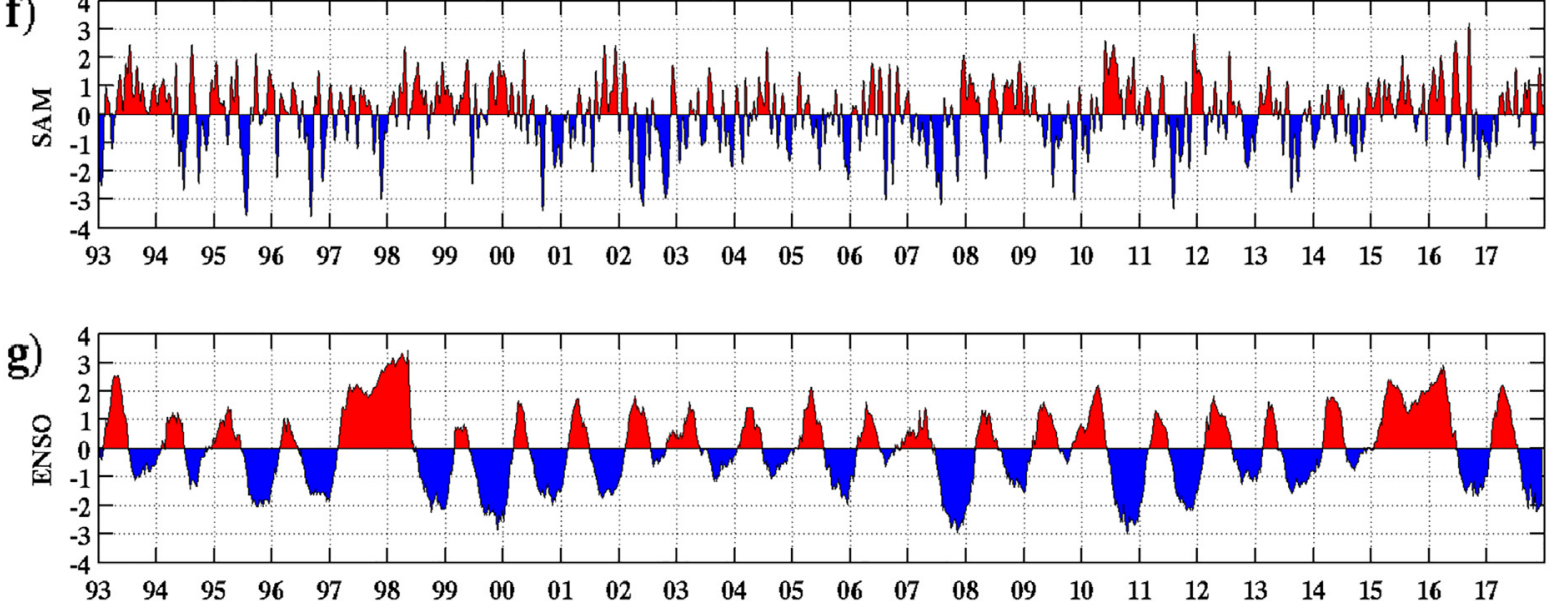
in particular significant peaks at 50 and at 23, 27 days (Fig. 9c). It is to be noted that in the 25 year-long time series, the semi-annual and annual peaks are above the $95 \%$ confidence level. Those periods are reminiscent of those found in the Koenig et al. (2016) transport time series. The monthly mean transports show two maxima, one in May and one in October, and lower values (below the mean) in austral summer (November to February) and in June (Fig. 9e).

We examined the low frequency variability from monthly smoothed transport time series. The spectrum shows a semi-annual $\left(14 \mathrm{~Sv}^{2}\right)$ and annual $\left(9 \mathrm{~Sv}^{2}\right)$ bumps and no significant energy at periods larger than 450 days (Fig. 9d). A wavelet analysis of the monthly smoothed transport shows that significant energy near the semiannual period is omnipresent throughout the time series whereas the energy at the annual period is more intermittent (not shown).

As in Koenig et al. (2016) we examined potential coherences between total transport variations and large-scale climate indices such as the South Annular Mode (SAM) and the El Nino Southern Oscillation (ENSO) shown in Fig. 9f and $\mathrm{g}$. The correlations of the total ACC transport with the SAM and ENSO indices are not stationary (Fig. 10). The total transport is strongly correlated $(r>0.8)$ and in phase with the SAM index at around the biannual period after 2006 (Fig. 10a). Significant correlations also appear at smaller periods but more intermittently between 1993 and 2000. The total transport is also significantly correlated with the ENSO index at the annual period from 2002 to 2006 with a 3 month lag (Fig. 10b), at the time when the total transport shows no coherence with the SAM index (Fig. 10a). As noted in Koenig et al. (2016), the SAM and ENSO influences are intermittent and epochdependent. The wavelet coherence analysis suggests that the total transport is influenced by the SAM during 1993-2000 and 2008-2012, by ENSO during 2002-2006, and finally by a combination of ENSO and SAM during 2013-2016 at periods of a year and longer.

\section{Discussion}

GLORYS12 reanalysis assimilates along-track SLA from satellite altimetry data. GLORYS12 surface velocities have a larger variability (surface EKE) than altimetryderived surface geostrophic velocities $\left(>200 \mathrm{~cm}^{2} \mathrm{~s}^{-2}\right.$, i.e. about $20 \%$ ). These differences are partially due to the spatial resolution of the model $\left(1 / 12^{\circ}\right.$ versus $1 / 4^{\circ}$ for gridded altimetry). Subsampling GLORYS12 surface velocities (after averaging over 9 grid points $-3 \times 3$ ) to a $1 / 4$ of a degree leads to an EKE reduction of $15 \%$ on average. Horizontal resolution is an important factor, and not the only one. Model EKE also includes contribution from Ekman velocities and ageostrophic motions.

GLORYS12 velocities compare well to the currentmeter data from the DRAKE and cDrake experiments in terms of means and standard deviations, and the correlations between the model and observed velocities time series are mostly significant (above 99\% confidence level, correlations being lower with the near-bottom C-Drake velocities). However, we note that GLORYS12 systematically underestimates the velocity variability above the continental slope off Tierra de Fuego (variance ellipse axes are underestimated by $5 \mathrm{~cm} \mathrm{~s}^{-1}$ compared to current-meter observations). Model resolution $\left(1 / 12^{\circ}\right)$ may be not sufficient yet to account for the variability on the slope. Chassignet and $\mathrm{Xu}$ (2017), in a modeling study of the energetic region of the Gulf Stream, showed that the increase in horizontal resolution (from $1 / 12^{\circ}$ to $1 / 50^{\circ}$ ) drastically improved the penetration of signals into the deep ocean.

We computed the total volume transport time series across three sections in Drake Passage (Fig. 1). The time series are highly correlated $(r>0.95)$ and the difference in their means provides an estimate of the uncertainty of $3 \mathrm{~Sv}$. The mean total volume transport over the 25 years of the reanalysis (1993-2017) is $155 \pm 3 \mathrm{~Sv}$. Annual mean values span a rather small range of $12 \mathrm{~Sv}$ (148 Sv in 2007 and $160 \mathrm{~Sv}$ in 1993).

GLORYS12 model mean transport values at the time of the Renault et al. (2011) estimates from LADCP are within the error bars of the observations (a model transport of $149 \mathrm{~Sv}$ to be compared to $145 \pm 8 \mathrm{~Sv}$ for January 16-26, 2006). GLORYS12 mean values also agree with the Southern Ocean State Estimate (SOSE, $1 / 6^{\circ}$ ) mean transport of $149 \mathrm{~Sv}$ over six years from 2005 to 2010 (Peña-Molino et al., 2014) (GLORYS12 mean of $151 \pm 3 \mathrm{~Sv}$ over the same period). GLORYS12 mean volume transport over 1993-2010 (157 $\pm 3 \mathrm{~Sv})$ is also similar to the nineensemble mean of $152 \pm 19 \mathrm{~Sv}$ over the same period from lower resolution reanalyses (resolution ranging from 1 to 1/4) (Uotila et al., 2019). The 20-year (1993-2012) GLORYS12 mean transport in the upper $3000 \mathrm{~m}$ $(149 \pm 2 \mathrm{~Sv})$ is $8 \mathrm{~Sv}$ larger than Koenig et al. (2014) estimate $(141 \pm 2.7 \mathrm{~Sv})$ whereas the range in annual means is $5 \mathrm{~Sv}$ smaller. GLORYS12 total transport over the

Fig. 9. (a) Time series of total ACC volume transport across the Section 1 (blue line in Fig. 1) from GLORYS12 (in Sv) (in blue) with superimposed smoothed time series obtained using a 1-month low-pass filter (in red). (b) Yearly averages of the transport from January 1993 to December 2017. Red colored bars indicate in situ observations periods from DRAKE and cDrake projects. The black horizontal line marks the mean model transport for the 1993-2017. The standard deviation is shown by the blue line centered on each bar. Variance-preserving spectra of (c) the full-time resolution transport time series (by averaging over groups of 7 adjacent frequencies) and (d) the monthly smoothed transport time series (by averaging over groups of 11 adjacent frequencies). The dotted lines show the $95 \%$ confidence level against the red noise background from a first order autoregressive process. The $y$-axis is the power in $\mathrm{Sv}^{2}$. (e) Monthly averages of the total transport. Time series of detrended SAM (f) and ENSO (g) index with a 1-month low-pass filter. 


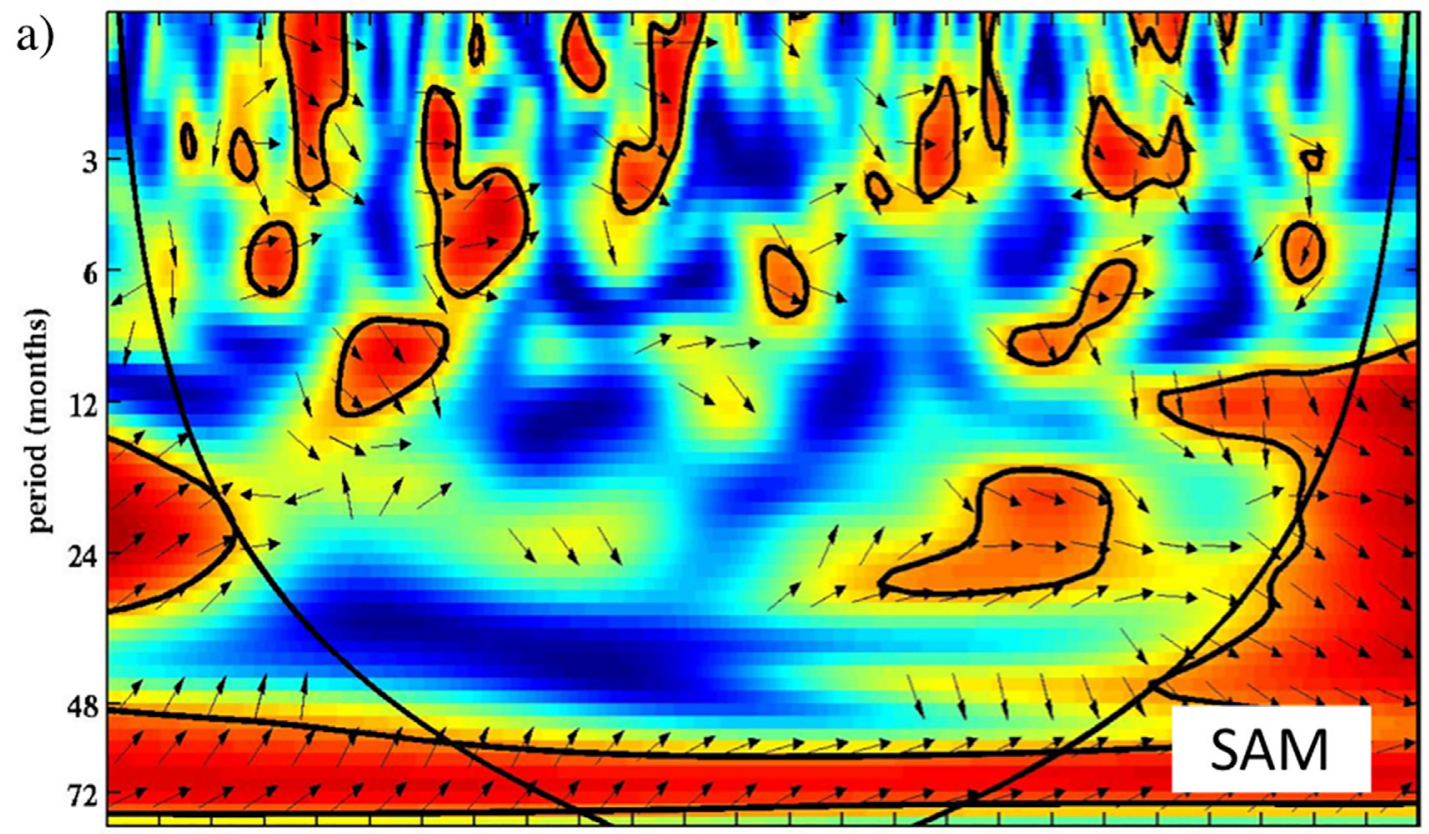

$\begin{array}{lllllllllllllllllllllllll}93 & 94 & 95 & 96 & 97 & 98 & 99 & 00 & 01 & 02 & 03 & 04 & 05 & 06 & 07 & 08 & 09 & 10 & 11 & 12 & 13 & 14 & 15 & 16 & 17\end{array}$

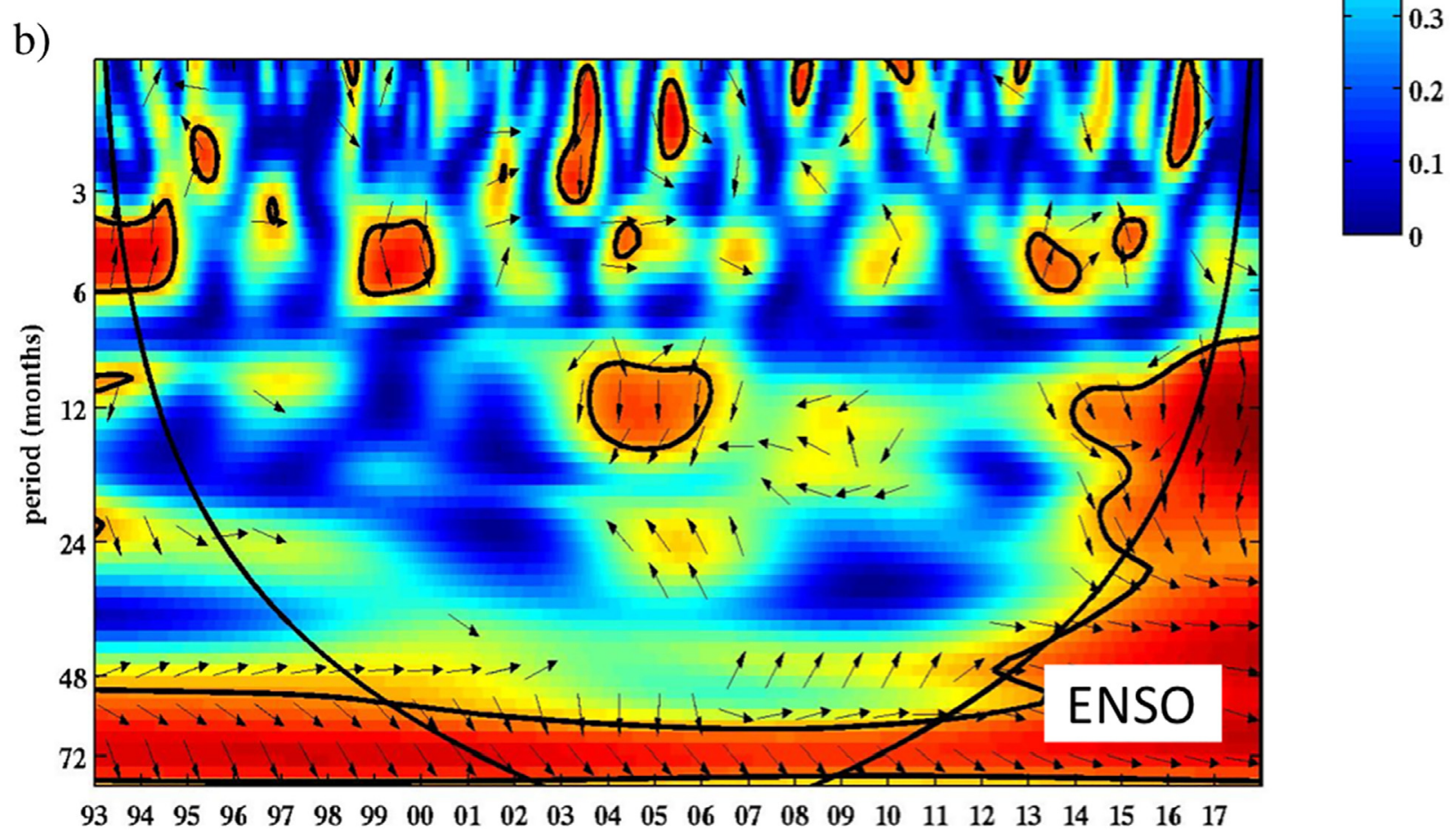

Fig. 10. Wavelet coherence between the total ACC transport (across Section 1) and (a) the SAM index and (b) the Nino 3 index. Time series have all been smoothed with a one month low-pass filter. The correlation is shown in color and the arrows indicate the phase. The black lines indicate the $95 \% \mathrm{CL}$ and the cutoff region to avoid edge effects.

cDrake period (2007-2011) $(151 \pm 2 \mathrm{~Sv})$ is well below the estimate of $173.3 \pm 10.7 \mathrm{~Sv}$ from the cDrake data (Donohue et al., 2016), in spite of the relatively good correspondence with the near bottom cDrake velocity measurements. Determining the absolute transport through
Drake Passage remains a challenge and GLORYS12 is potentially a useful tool to understand differences between estimates. Further analysis is needed in particular for separating the barotropic and baroclinic components in the model. 
The standard deviation of the GLORYS12 total volume transport $(6.7 \mathrm{~Sv})$ is smaller than the few existing estimates: $8.1 \mathrm{~Sv}$ for 4 years of baroclinic transport in Chidichimo et al. (2014) and $10 \mathrm{~Sv}$ for 20 years of transport in the upper $3000 \mathrm{~m}$ in Koenig et al. (2016). This smaller standard deviation needs further analysis, and may be related to the too small model velocity variability on the northern continental slope.

The 25 year-long GLORYS12 total transport time series shows significant energy at the intraseasonal, semi-annual and annual periods. Those periods are reminiscent of those found in Koenig et al. (2016). The outstanding peak at 50 days $\left(30 \mathrm{~Sv}^{2}\right)$ also dominated intra-seasonal variations in the 20-year long transport from Koenig et al. (2016) $\left(40 \mathrm{~Sv}^{2}\right)$. All the sections under consideration cross the Yaghan Basin which hosts basin modes. The 50-day period has been interpreted as an energetic harmonic of the fundamental basin mode ( $T=99$ days) in the Yaghan Basin resulting from resonant amplification due to an external forcing (the SAM index spectrum also peaks at 50 days) (Koenig et al., 2016).

The 25-year long transport series does not show any significant low frequency variation (beyond 2 years) or trend. As in Koenig et al. (2016), we did not find any systematic relationship between climatic indices such as SAM or ENSO and the ACC transport, the covariability of the ACC transport with the SAM or ENSO index depends on a particular epoch and the considered periodicity.
This first assessment of GLORYS12 velocities in Drake Passage is very encouraging and suggests that GLORYS12 can provide further insight into the complex circulation in Drake Passage. Synoptic situations indicative of large vertical velocities such as the ones over the WSR as described in Sudre et al. (2011) and Renault et al. (2011) will be examined in a future study.

\section{Acknowledgements}

The comments and suggestions of two anonymous reviewers helped to improve the manuscript. The authors are grateful to the CNES (Center National d'Etudes Spatiales) for constant support (DRAKE, then PHANTOM projects).

The satellite data and model outputs are available at Copernicus Marine Environment Monitoring Service (CMEMS; http://marine.copernicus.eu/). The DRAKE data (Provost et al., 2019a and b) are available at Seanoe (https://www.seanoe.org/data/00500/61214/ and https:// www.seanoe.org/data/00500/61186/) and the cDrake data (Tracey et al., 2015) at https://data.nodc.noaa.gov/ (NCEI Accession 0121256).

Appendix.

Table 1a

Comparison Drake 20062008 - Glorys12.

\begin{tabular}{|c|c|c|c|c|c|c|}
\hline Mooring & Depth (m) & N Obs. (day) & $\begin{array}{l}|\bar{V}|(\mathrm{cm} / \mathrm{s}) \\
\text { in situ/Diff. }\end{array}$ & $\begin{array}{l}\text { Major axis }(\mathrm{cm} / \mathrm{s}) \\
\text { in situ/Diff. }\end{array}$ & $\begin{array}{l}\text { Minor axis }(\mathrm{cm} / \mathrm{s}) \\
\text { in situ/Diff. }\end{array}$ & $\begin{array}{l}\mathrm{R} \\
\mathrm{V} \text {. across }\end{array}$ \\
\hline M1 & $\begin{array}{l}59 \\
376 \\
850\end{array}$ & $\begin{array}{l}798 \\
789 \\
434\end{array}$ & $\begin{array}{l}20.4 / 0.5 \\
16.5 / 0.8 \\
11.6 /-1.1\end{array}$ & $\begin{array}{l}22.6 / 5.4 \\
18.5 / 6.2 \\
14.4 / 4.7\end{array}$ & $\begin{array}{l}12.9 / 5.3 \\
9.4 / 5.0 \\
6.0 / 3.2\end{array}$ & $\begin{array}{l}0.57 \\
0.65 \\
0.77\end{array}$ \\
\hline M3 & $\begin{array}{l}376 \\
900 \\
1894\end{array}$ & $\begin{array}{l}812 \\
812 \\
812\end{array}$ & $\begin{array}{l}19.2 / 4.2 \\
14.2 / 1.3 \\
10.6 / 0.0\end{array}$ & $\begin{array}{l}20.8 / 3.8 \\
12.5 / 2,2 \\
9.4 / 1.8\end{array}$ & $\begin{array}{l}17.1 / 2.1 \\
11.4 / 0.7 \\
7.8 / 0.0\end{array}$ & $\begin{array}{l}0.52 \\
0.46 \\
0.18\end{array}$ \\
\hline M4 & $\begin{array}{l}426 \\
949 \\
2413\end{array}$ & $\begin{array}{l}809 \\
809 \\
809\end{array}$ & $\begin{array}{l}7.0 /-3.9 \\
10.4 /-1.2 \\
13.2 /-2.1\end{array}$ & $\begin{array}{l}23.3 /-1.6 \\
16.9 /-0.9 \\
11.6 / 0,5\end{array}$ & $\begin{array}{l}18.8 / 0.1 \\
14.2 / 0.9 \\
11.0 / 3.1\end{array}$ & $\begin{array}{l}0.42 \\
0.38 \\
0.35\end{array}$ \\
\hline M5 & $\begin{array}{l}564 \\
1072 \\
2604\end{array}$ & $\begin{array}{l}778 \\
778 \\
778\end{array}$ & $\begin{array}{l}21.5 /-1.9 \\
12.2 / 1.2 \\
3.2 /-3.1\end{array}$ & $\begin{array}{l}18.3 / 1.9 \\
10.5 /-1.8 \\
7.8 /-1.7\end{array}$ & $\begin{array}{l}15.7 / 0.6 \\
8.9 /-5.6 \\
4.1 /-5.1\end{array}$ & $\begin{array}{l}0.63 \\
0.57 \\
0.43\end{array}$ \\
\hline M6 & $\begin{array}{l}235 \\
820 \\
2410\end{array}$ & $\begin{array}{l}805 \\
805 \\
805\end{array}$ & $\begin{array}{l}21.5 /-1.1 \\
13.5 /-1.7 \\
5.7 / 0.9\end{array}$ & $\begin{array}{l}14.4 /-1.8 \\
8.3 /-2.5 \\
5.3 /-0.3\end{array}$ & $\begin{array}{l}11.9 /-1.1 \\
6.3 /-1.3 \\
3.7 / 1.0\end{array}$ & $\begin{array}{l}0.67 \\
0.56 \\
0.24\end{array}$ \\
\hline M7 & $\begin{array}{l}460 \\
980 \\
2515\end{array}$ & $\begin{array}{l}690 \\
690 \\
803\end{array}$ & $\begin{array}{l}0.7 /-0.5 \\
2.2 / 0.8 \\
3.9 /-0.9\end{array}$ & $\begin{array}{l}7.2 /-2.6 \\
6.2 /-2.9 \\
6.4 /-1.1\end{array}$ & $\begin{array}{l}6.2 /-3.2 \\
5.6 /-3.1 \\
5.8 /-1.4\end{array}$ & $\begin{array}{l}0.36 \\
0.42 \\
0.27\end{array}$ \\
\hline M9 & $\begin{array}{l}1045 \\
2510\end{array}$ & $\begin{array}{l}800 \\
800\end{array}$ & $\begin{array}{l}10.2 / 6.5 \\
8.7 / 5.8\end{array}$ & $\begin{array}{l}10.6 /-1.5 \\
9.0 / 0.8\end{array}$ & $\begin{array}{l}8.6 / 1.6 \\
8.2 / 1.4\end{array}$ & $\begin{array}{l}\text { NS } \\
\text { NS }\end{array}$ \\
\hline M10 & $\begin{array}{l}460 \\
1000 \\
2560\end{array}$ & $\begin{array}{l}438 \\
774 \\
324\end{array}$ & $\begin{array}{l}2.4 /-4.3 \\
1.8 /-0.5 \\
3.8 / 1.0\end{array}$ & $\begin{array}{l}8.6 /-7.1 \\
7.4 / 0.2 \\
6.1 /-0.9\end{array}$ & $\begin{array}{l}4.6 / 4.5 \\
4.7 / 1.7 \\
3.9 / 4.3\end{array}$ & $\begin{array}{l}\text { NS } \\
\text { NS } \\
\text { NS }\end{array}$ \\
\hline
\end{tabular}


Table $1 b$

Comparison Drake 20082009 - Glorys12.

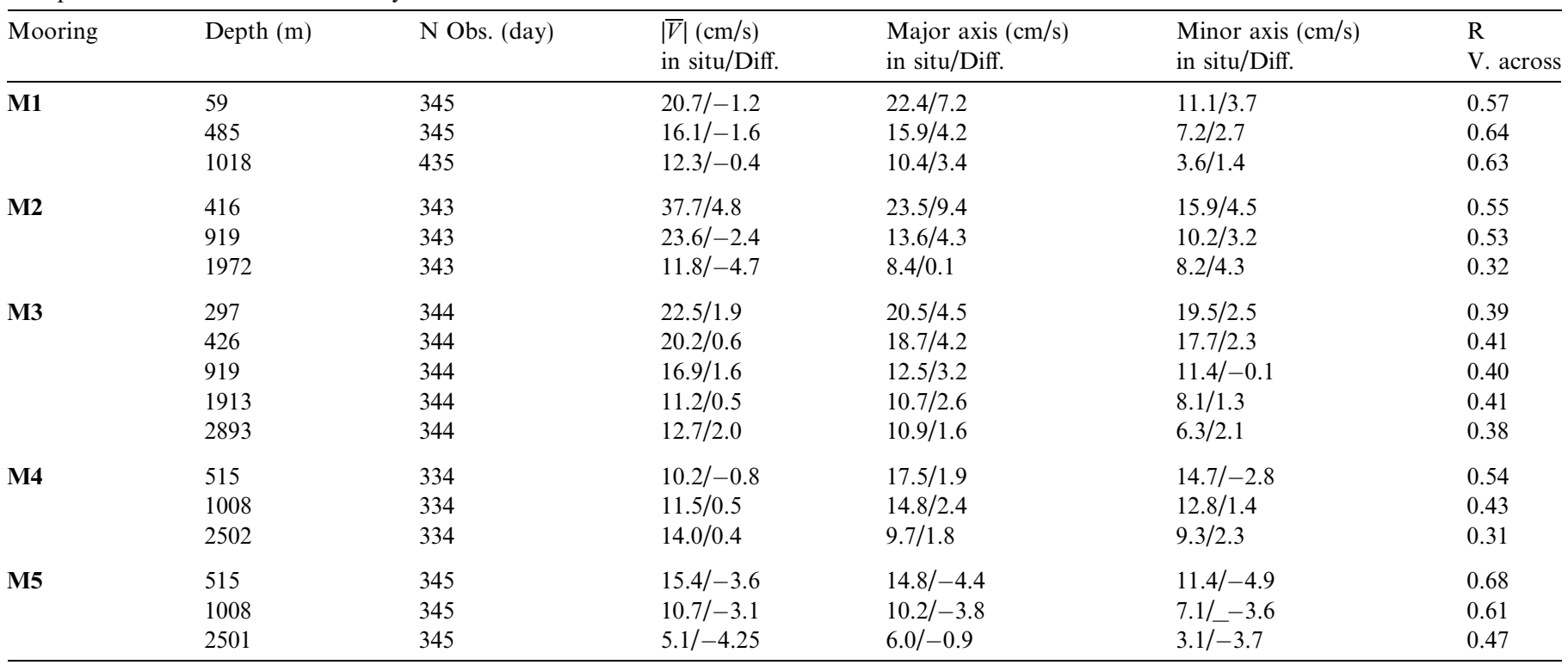

Table 2a

Comparison Altimetry-Glorys12 (2006-2008).

\begin{tabular}{|c|c|c|c|c|c|}
\hline Moorings & N Obs. (day) & $\begin{array}{l}|\mathrm{V}|(\mathrm{cm} / \mathrm{s}) \\
\text { Mean Altimetry/Diff. }\end{array}$ & $\begin{array}{l}\text { Major axis }(\mathrm{cm} / \mathrm{s}) \\
\text { Mean Altimetry/Diff. }\end{array}$ & $\begin{array}{l}\text { Minor axis }(\mathrm{cm} / \mathrm{s}) \\
\text { Mean Altimetry/Diff. }\end{array}$ & $\begin{array}{l}\mathrm{R} \\
\text { across }\end{array}$ \\
\hline M1 & 812 & $23.1 /-1.3$ & $16.3 /-2.7$ & $4.3 /-5.1$ & 0.6 \\
\hline M3 & 812 & $21.2 / 2.3$ & $21.2 /-0.4$ & $16.7 /-1.4$ & 0.4 \\
\hline M5 & 812 & $25.6 /-3.9$ & $23.9 /-8.6$ & $17.8 /-5.1$ & 0.6 \\
\hline M6 & 812 & $26.8 /-1.5$ & $17.7 /-1.5$ & $12.2 /-4.7$ & 0.6 \\
\hline M7 & 812 & $2.5 /-0.8$ & $8.4 /-4.5$ & $5.7 /-5.2$ & 0.4 \\
\hline
\end{tabular}

Table $2 b$

Comparison Altimetry-Glorys12 (2008-2009).

\begin{tabular}{lllll}
\hline Moorings & N Obs. (day) & $\begin{array}{l}|\mathrm{V}|(\mathrm{cm} / \mathrm{s}) \\
\text { Mean Altimetry/Diff. }\end{array}$ & $\begin{array}{l}\text { Major axis (cm/s) } \\
\text { Mean Altimetry/Diff. }\end{array}$ & $\begin{array}{l}\text { Minor axis (cm/s) } \\
\text { Mean Altimetry/Diff. }\end{array}$ \\
\hline M1 & 355 & $23 /-3.5$ & $11.5 /-5.1$ & $6.7 /-2.1$ \\
M2 & 355 & $32.2 /-7.2$ & $17.8 /-0.1$ & $14.1 /-1.6$ \\
M3 & 355 & $20.7 /-4.4$ & $22.1 / 0.3$ & $15.3 /-2.1$ \\
M4 & 355 & $10.8 /-0.9$ & $21.9 /-1.5$ & $15.5 /-3.7$ \\
M5 & 355 & $21.2 /-6.7$ & $20 /-8.7$ & $26.3 /-3.8$ \\
\hline
\end{tabular}

Table 3a

Comparison cDrake 20072011 - Glorys12.

\begin{tabular}{|c|c|c|c|c|c|c|}
\hline \multirow[t]{2}{*}{ Cpies } & \multirow[t]{2}{*}{ N Obs. (day) } & \multirow[t]{2}{*}{ Depth In situ (m) } & \multirow{2}{*}{$\begin{array}{l}|\mathrm{V}|(\mathrm{cm} / \mathrm{s}) \\
\text { Mean in situ/Diff. }\end{array}$} & \multirow{2}{*}{$\begin{array}{l}\text { Major axis }(\mathrm{cm} / \mathrm{s}) \\
\text { Mean in situ/Diff. }\end{array}$} & \multirow[t]{2}{*}{$\begin{array}{l}\text { Minor axis }(\mathrm{cm} / \mathrm{s}) \\
\text { Mean in situ/Diff. }\end{array}$} & \multirow[t]{2}{*}{$\begin{array}{l}\mathrm{R} \\
\mathrm{u} / \mathrm{v} \\
\text { across/along }\end{array}$} \\
\hline & & & & & & \\
\hline $\mathrm{A} 01$ & 1162 & 4135 & $2.6 /-0.8$ & $11.7 / 2.1$ & $8.7 / 2.4$ & $\begin{array}{l}\mathrm{NS} / \mathrm{NS} \\
\mathrm{NS} / \mathrm{NS}\end{array}$ \\
\hline A02 & 1437 & 4408 & $3.2 /-0.3$ & $15.5 / 4.5$ & $9.4 / 1.8$ & $\begin{array}{l}\mathrm{NS} /-0.2 \\
\mathrm{NS} /-0.2\end{array}$ \\
\hline A03 & 1472 & 4410 & $2.7 /-6.6$ & $15.4 /-2.4$ & $8.6 / 3.7$ & $\begin{array}{l}0.4 /-0.4 \\
-0.2 /-0.4\end{array}$ \\
\hline
\end{tabular}


Table 3a (continued)

\begin{tabular}{|c|c|c|c|c|c|c|}
\hline Cpies & N Obs. (day) & Depth In situ (m) & $\begin{array}{l}|\mathrm{V}|(\mathrm{cm} / \mathrm{s}) \\
\text { Mean in situ/Diff. }\end{array}$ & $\begin{array}{l}\text { Major axis }(\mathrm{cm} / \mathrm{s}) \\
\text { Mean in situ/Diff. }\end{array}$ & $\begin{array}{l}\text { Minor axis }(\mathrm{cm} / \mathrm{s}) \\
\text { Mean in situ/Diff. }\end{array}$ & $\begin{array}{l}\mathrm{R} \\
\mathrm{u} / \mathrm{v} \\
\text { across/along }\end{array}$ \\
\hline B01 & 1167 & 3943 & $1.8 /-3.9$ & $15.5 / 0.3$ & $9.3 / 0.7$ & $\begin{array}{l}\mathrm{NS} / \mathrm{NS} \\
\mathrm{NS} / \mathrm{NS}\end{array}$ \\
\hline B02 & 1473 & 4048 & $4.1 /-0.5$ & $11.1 / 1.7$ & $3.2 /-1.8$ & $\begin{array}{l}0.2 / 0.2 \\
0.2 / \mathrm{NS}\end{array}$ \\
\hline B03 & 1470 & 4090 & $14.7 /-0.8$ & $10.4 / 0.9$ & $7.2 /-3.0$ & $\begin{array}{l}0.2 /-0.1 \\
\mathrm{NS} /-0.2\end{array}$ \\
\hline $\mathrm{C} 01$ & 856 & 497 & $4.9 /-0.7$ & $11.3 /-0.7$ & $8.6 / 0.7$ & $\begin{array}{l}0.4 / 0.3 \\
0.4 /-0.2\end{array}$ \\
\hline $\mathrm{C} 02$ & 1071 & 1802 & $12.8 /-1.9$ & $6.8 /-0.4$ & $1.5 / 0.7$ & $\begin{array}{l}0.6 / 0.5 \\
0.6 /-0.5\end{array}$ \\
\hline $\mathrm{C} 03$ & 1101 & 3773 & $4.9 /-1.3$ & $7.3 / 2.3$ & $1.9 /-0.9$ & $\begin{array}{l}0.3 / 0.2 \\
0.3 / \mathrm{NS}\end{array}$ \\
\hline $\mathrm{C} 04$ & 1165 & 3938 & $3.5 /-0.6$ & $10.6 / 0.9$ & 7.0/1.4 & $\begin{array}{l}\text { NS/NS } \\
\text { NS/NS }\end{array}$ \\
\hline $\mathrm{C} 05$ & 342 & 3899 & $5.2 /-2.5$ & $9.3 / 5.2$ & $7.0 / 0.4$ & $\begin{array}{l}0.4 /-0.2 \\
0.1 /-0.3\end{array}$ \\
\hline $\mathrm{C} 06$ & 1471 & 4002 & $3.3 /-1.8$ & $10.9 /-1.6$ & $8.9 / 0.5$ & $\begin{array}{l}0.2 / \mathrm{NS} \\
0.2 / \mathrm{NS}\end{array}$ \\
\hline $\mathrm{C} 07$ & 1471 & 4215 & $2.2 /-4.2$ & $12.2 /-2.6$ & $10.6 / 1.8$ & $\begin{array}{l}0.2 /-0.2 \\
\mathrm{NS} /-0.2\end{array}$ \\
\hline $\mathrm{C} 08$ & 1175 & 3753 & $9.4 /-3.7$ & $9.3 / 1.3$ & $7.3 / 0.2$ & $\begin{array}{l}0.2 /-0.1 \\
\text { NS/ }-0.2\end{array}$ \\
\hline C09 & 1472 & 4080 & $11.1 /-4.3$ & $10.2 /-1.2$ & $8.8 / 1.7$ & $\begin{array}{l}0.2 / \mathrm{NS} \\
0.2 / \mathrm{NS}\end{array}$ \\
\hline $\mathrm{C} 10$ & 1477 & 2541 & $7.7 / 1.0$ & $6.2 /-0.5$ & $6.0 / 0.2$ & $\begin{array}{l}0.3 / 0.2 \\
0.4 /-0.2\end{array}$ \\
\hline $\mathrm{C} 11$ & 1476 & 3912 & $3.7 /-1.0$ & $7.8 /-1.5$ & $3.2 /-1.1$ & $\begin{array}{l}0.2 / \mathrm{NS} \\
0.1 /-0.2\end{array}$ \\
\hline $\mathrm{C} 12$ & 367 & 4072 & $5.4 / 1.8$ & $5.6 /-0.4$ & $4.8 /-1.1$ & $\begin{array}{l}0.3 / \mathrm{NS} \\
0.3 /-0.2\end{array}$ \\
\hline $\mathrm{C} 13$ & 1473 & 4031 & $3.5 /-3.9$ & $3.8 /-2.9$ & 2. $9 /-2.6$ & $\begin{array}{l}0.4 / \mathrm{NS} \\
0.4 /-0.2\end{array}$ \\
\hline $\mathrm{C} 14$ & 1473 & 3735 & $1.5 /-0.1$ & $4.00 /-1.7$ & $2.6 /-1.1$ & $\begin{array}{l}0.1 / \mathrm{NS} \\
0.1 / \mathrm{NS}\end{array}$ \\
\hline $\mathrm{C} 15$ & 1422 & 3908 & $2.3 / 1.1$ & $4.7 /-0.6$ & $3.5 / 0.9$ & $\begin{array}{l}\mathrm{NS} / \mathrm{NS} \\
\mathrm{NS} / \mathrm{NS}\end{array}$ \\
\hline $\mathrm{C} 16$ & 1345 & 2548 & $6.0 / 0.7$ & $6.1 / 0.0$ & $5.5 /-0.9$ & $\begin{array}{l}0.3 / 0.2 \\
0.3 /-0.3\end{array}$ \\
\hline $\mathrm{C} 17$ & 1473 & 1282 & $0.4 /-7.6$ & $1.0 / 1.7$ & $0.6 /-4.8$ & $\begin{array}{l}\text { NS/NS } \\
\text { NS/NS }\end{array}$ \\
\hline $\mathrm{C} 18$ & 377 & 3673 & $10.2 /-11.3$ & $8.5 /-3.2$ & $3.9 / 0.1$ & $\begin{array}{l}0.5 /-0.3 \\
0.4 /-0.5\end{array}$ \\
\hline $\mathrm{C} 19$ & 1456 & 3506 & $7.5 /-0.4$ & $13.2 /-0.6$ & $9.0 / 0.7$ & $\begin{array}{l}0.3 / \mathrm{NS} \\
0.3 /-0.2\end{array}$ \\
\hline $\mathrm{C} 20$ & 1449 & 3904 & $9.9 / 1.2$ & $9.4 /-0.6$ & $6.8 / 2.6$ & $\begin{array}{l}\text { NS/NS } \\
\text { NS/NS }\end{array}$ \\
\hline D01 & 1470 & 4084 & $9.2 /-1.7$ & $10.8 / 0.0$ & $8.4 /-0.3$ & $\begin{array}{l}\text { NS/NS } \\
\text { NS/NS }\end{array}$ \\
\hline D02 & 729 & 3992 & $7.5 /-3.7$ & $10.6 /-1.1$ & $8.5 / 1.3$ & $\begin{array}{l}0.2 /-0.2 \\
0.1 /-0.2\end{array}$ \\
\hline D03 & 1472 & 3995 & $12.9 / 3.0$ & $11.3 / 0.4$ & $6.9 /-0.2$ & $\begin{array}{l}0.3 / \mathrm{NS} \\
0.1 / \mathrm{NS}\end{array}$ \\
\hline E01 & 1466 & 4115 & $6.6 /-0.5$ & $10.7 /-0.4$ & $9.0 /-0.6$ & $\begin{array}{l}0.2 / 0.1 \\
0.2 / \mathrm{NS}\end{array}$ \\
\hline E02 & 1465 & 4105 & $16.5 /-0.9$ & $11.2 / 1.5$ & $9.5 /-0.4$ & $\begin{array}{l}0.2 / \mathrm{NS} \\
0.2 / \mathrm{NS}\end{array}$ \\
\hline E03 & 1466 & 3982 & $0.7 /-1.8$ & 10. $9 /-1.1$ & $9.4 / 1.7$ & $\begin{array}{l}0.3 / \mathrm{NS} \\
0.3 / \mathrm{NS}\end{array}$ \\
\hline F01 & 1277 & 4236 & $8.7 /-1.1$ & $10.6 /-1.7$ & $8.9 /-2.0$ & $\begin{array}{l}0.3 / \mathrm{NS} \\
0.3 / \mathrm{NS}\end{array}$ \\
\hline F02 & 1467 & 4121 & $13.5 /-4.4$ & $9.9 / 0.9$ & $9.1 /-2.2$ & $\begin{array}{l}0.5 / \mathrm{NS} \\
0.4 / \mathrm{NS} \\
\text { on next page) }\end{array}$ \\
\hline
\end{tabular}


Table 3a (continued)

\begin{tabular}{|c|c|c|c|c|c|c|}
\hline Cpies & N Obs. (day) & Depth In situ (m) & $\begin{array}{l}|\mathrm{V}|(\mathrm{cm} / \mathrm{s}) \\
\text { Mean in situ/Diff. }\end{array}$ & $\begin{array}{l}\text { Major axis }(\mathrm{cm} / \mathrm{s}) \\
\text { Mean in situ/Diff. }\end{array}$ & $\begin{array}{l}\text { Minor axis }(\mathrm{cm} / \mathrm{s}) \\
\text { Mean in situ/Diff. }\end{array}$ & $\begin{array}{l}\mathrm{R} \\
\mathrm{u} / \mathrm{v} \\
\text { across/along }\end{array}$ \\
\hline $\bar{F} 03$ & 1373 & 3817 & $14.0 / 0.6$ & $9.6 /-0.5$ & $7.3 /-1.4$ & $\begin{array}{l}0.3 / \mathrm{NS} \\
0.3 / \mathrm{NS}\end{array}$ \\
\hline G01 & 1468 & 4404 & $8.2 / 2.1$ & $10.4 / 1.2$ & $9.8 /-0.6$ & $\begin{array}{l}0.4 / \mathrm{NS} \\
0.4 /-0.2\end{array}$ \\
\hline G02 & 1389 & 4065 & $21.5 /-2.8$ & $11.8 /-0.9$ & $9.3 / 0.6$ & $\begin{array}{l}0.4 / 0.3 \\
0.4 / \mathrm{NS}\end{array}$ \\
\hline G03 & 1104 & 3649 & $7.8 /-2.2$ & $8.6 / 1.3$ & $6.3 /-2.4$ & $\begin{array}{l}0.2 / 0.1 \\
0.2 / \mathrm{NS}\end{array}$ \\
\hline
\end{tabular}

Table $3 b$

Comparison cDrake mooring 20072009 - Glorys12.

\begin{tabular}{|c|c|c|c|c|c|c|}
\hline Cpies & N Obs. (day) & Depth (m) & $\begin{array}{l}|\mathrm{V}|(\mathrm{cm} / \mathrm{s}) \\
\text { Mean in situ/Diff. }\end{array}$ & $\begin{array}{l}\text { Major axis }(\mathrm{cm} / \mathrm{s}) \\
\text { Mean in situ/Diff. }\end{array}$ & $\begin{array}{l}\text { Minor axis }(\mathrm{cm} / \mathrm{s}) \\
\text { Mean in situ/Diff. }\end{array}$ & $\begin{array}{l}\mathrm{R} \\
\mathrm{V} . \text { across }\end{array}$ \\
\hline $\begin{array}{l}\text { M1_1 } \\
\text { M1_2 } \\
\text { M1_3 }\end{array}$ & 737 & $\begin{array}{l}916 \\
1216 \\
1416\end{array}$ & $\begin{array}{l}7.7 /-1.7 \\
6.7 /-1.9 \\
5.1 /-0.1\end{array}$ & $\begin{array}{l}8.3 /-2.7 \\
4.7 /-2.9 \\
3.3 /-1.1\end{array}$ & $\begin{array}{l}1.9 /-0.1 \\
0.9 /-0.5 \\
0.6 /-0.3\end{array}$ & $\begin{array}{l}0.4 \\
0.3 \\
0.2\end{array}$ \\
\hline $\begin{array}{l}\text { M2_1 } \\
\text { M1_2 }\end{array}$ & 736 & $\begin{array}{l}2836 \\
3136\end{array}$ & $\begin{array}{l}1.9 /-5.6 \\
3.8 /-2.3\end{array}$ & $\begin{array}{l}7.5 / 3.4 \\
7.8 /-2.4\end{array}$ & $\begin{array}{l}1.6 / 1.1 \\
1.3 /-0.3\end{array}$ & $\begin{array}{l}\text { NS } \\
0.2\end{array}$ \\
\hline
\end{tabular}

\section{References}

Artana, C., Lellouche, J.M., Park, Y.-H., Garric, G., Koenig, Z., Sennéchael, N., Ferrari, R., Piola, A.R., Saraceno, M., Provost, C., 2018a. Fronts of the Malvinas Current System: surface and subsurface expressions revealed by satellite altimetry, Argo floats, and Mercator operational model output. J. Geophys. Res. Oceans 123, 5261-5285. https://doi.org/10.1029/2018JC013887.

Artana, C., Lellouche, J.-M., Sennéchael, N., Provost, C., 2018b. The open-ocean side of the Malvinas Current in Argo float data and 25 years of reanalyses from Mercator operational system. J. Geophys. Res. Oceans 123, 8489-8507. https://doi.org/10.1029/2018JC014528.

Barré, N., Provost, C., Sennéchael, N., Lee, J.H., 2008. Circulation in the Ona Basin, Southern Drake Passage. J. Geophys. Res. Oceans 113, C04033. https://doi.org/10.1029/2007JC004549.

Barré, N., Provost, C., Renault, A., Sennéchael, N., 2011. Fronts, meanders and eddies in Drake Passage during the ANT-XXIII/3 cruise in January-February 2006: a satellite perspective. Deep Sea Res, Part II 58 (25-26), 2533-2554. https://doi.org/10.1016/j.dsr2.2011.01.003.

Bernie, D.J., Woolnough, S.J., Slingo, J.M., Guilyardi, E., 2005. Modeling diurnal and intraseasonal variability of the ocean mixed layer. J. Clim. 18, 1190-1202. https://doi.org/10.1175/JCLI3319.1.

Bricaud, C., Garric, G., Drillet, Y., 2018. Ocean mass and heat transport In CMEMS ocean state report. J. Oper. Oceanogr. 11 (sup1), s1-s142. https://doi.org/10.1080/1755876X.2018.1489208.

Cabanes, C., Grouazelm, A., von Schuckmann, K., Hamon, M., Turpin, V., Coatanoan, C., et al., 2013. The CORA dataset: Validation and diagnostics of in-situ ocean temperature and salinity measurements. Ocean Sci. 9 (1), 1-18. https://doi.org/10.5194/os-9-1-2013.

Chassignet, E.P., Xu, X., 2017. Impact of Horizontal $\left(1 / 12^{\circ}\right.$ to $\left.1 / 50^{\circ}\right)$ on the Gulf Stream separation, penetration and variability. J. Phys. Oceanogr. 47, 199-2021. https://doi.org/10.1175/jpo-D-17-0031.1.

Chereskin, T.K., Donohue, K.A., Watts, D.R., Tracey, K.L., Firing, Y., Cutting, A.L., 2009. Strong bottom currents and cyclogenesis in Drake Passage. Geophys. Res. Lett. 36, L23602. https://doi.org/10.1029/ 2009GL040940.
Chereskin, T.K., Donohue, K.A., Watts, D.R., 2012. cDrake: dynamics and transport of the Antarctic circumpolar current in Drake Passage. Oceanography 25 (3), 134-135.

Chidichimo, M.P., Donohue, K.A., Watts, D.R., Tracey, K.L., 2014. Baroclinic transport time series of the Antarctic Circumpolar Current measured in Drake Passage. J. Phys. Oceanogr. 44 (7), 1829-1853. https://doi.org/10.1175/JPO-D-13-071.1.

Chouaib, N., Stoehr, F., Provost, C., 2006. Variability of the Subantarctic and Polar fronts in the Drake Passage as deduced from altimetry. J. Mar. Res. 64, 669-693. https://doi.org/10.1357/002224006779367276.

Colin de Verdière, A., Ollitrault, M., 2016. A direct determination of the World Ocean barotropic circulation. J. Phys. Oceanogr. 46 (1), 255273. https://doi.org/10.1175/JPO-D-15-0046.1.

Cunningham, S., Alderson, S., King, B., Brandon, M., 2003. Transport and variability of the Antarctic Circumpolar Current in Drake Passage. J. Geophys. Res. 108 (C5), 8084. https://doi.org/10.1029/ $2001 \mathrm{JC} 001147$.

Ezraty R., Girard-Ardhuin, F., Piolle, J.F., Kaleschke, L., Heygster, G., 2007. Arctic and Antarctic sea ice concentration and Arctic sea ice drift estimated from Special Sensor Microwave data. User's Manual, Version 2.1, CERSAT.

Donohue, K.A., Tracey, K.L., Watts, D.R., Chidichimo, M.P., Chereskin, T.K., 2016. Mean antarctic circumpolar current transport measured in Drake passage. Geophys. Res. Lett. 43 (11), 760-767. https://doi.org/ 10.1002/2016GL070319.

Farneti, R., Downes, S.M., Griffies, S.M., Marsland, S.J., Behrens, E., Bentsen, M., Bi, D., Biastoch, A., Böning, C., Bozec, A., Canuto, V.M., Chassignet, E., Danabasoglu, G., Danilov, S., Diansky, N., Drange, H., Fogli, P.G., Gusev, A., Hallberg, R.W., Howard, A., Illack, M., Jung, T., Kelley, M., Large, W.G., Leboissetier, A., Long, M., Lu, J., Masina, S., Mishra, A., Navarra, A., Nurser, A.J.G., Patara, L., Samuels, B.L., Sidorenko, D., Tsujino, H., Uotila, P., Wang, Q., Yeager, S.G., 2015. An assessment of Antarctic Circumpolar Current and Southern Ocean meridional overturning circulation during 1958-2007 in a suite of interannual CORE-II simulations. Ocean Model. 93, 84-120. https:// doi.org/10.1016/j.ocemod.2015.07.009. 
Ferrari, R., Provost, C., Renault, A., Sennéchael, N., Barré, N., Park, Y.-H., Lee, J.H., 2012. Circulation in Drake Passage revisited using new current time-series and satellite altimetry. Part I: the Yaghan Basin. J. Geophys. Res. Oceans 117, C12024. https://doi.org/10.1029/ 2012JC008264.

Ferrari, R., Provost, C., Renault, A., Barré, N., Sennéchael, N., Park, Y. H., Lee, J.-H., 2013. Circulation in Drake Passage revisited using new current time-series and satellite altimetry. Part II: the Ona Basin. J. Geophys. Res. Oceans 118, 147-165. https://doi.org/10.1029/ 2012JC008193.

Ferrari, R., Provost, C., Park, Y.-H., Sennéchael, N., Koenig, Z., Sekma, H., Garric, G., Bourdallé-Badie, R., 2014. Heat fluxes across the Antarctic Circumpolar Current in Drake Passage: Mean flow and eddy contributions. J. Geophys. Res. Oceans 119, 6381-6402. https://doi. org/10.1002/2014JC010201.

Koenig, Z., Provost, C., Ferrari, R., Sennéchael, N., Rio, M.-H., 2014. Volume transport of the Antarctic Circumpolar Current: production and validation of a 20-year long time series obtained from in situ and satellite observations. J. Geophys. Res. Oceans 119, 5407-5433. https://doi.org/10.1002/2014JC009966.

Koenig, Z., Provost, C., Park, Y.-H., Ferrari, R., Sennéchael, N., 2016. Anatomy of the Antarctic Circumpolar Current volume transports through Drake Passage. J. Geophys. Res. Oceans 121, 2572-2595. https://doi.org/10.1002/2015JC011436.

Lellouche, J.-M., Le Galloudec, O., Drevillon, M., Regnier, C., Greiner, E., Garric, G., Ferry, N., Desportes, C., Testut, C.-E., Bricaud, C., Bourdalle-Badie, R., Tranchant, B., Benkiran, M., Drillet, Y., Daudin, A., De Nicola, C., 2013. Evaluation of global monitoring and forecasting systems at Mercator Ocean. Ocean Sci. 9, 57-81. https:// doi.org/10.5194/os-9-57-2013.

Lellouche, J.-M., Greiner, E., Le Galloudec, O., Garric, G., Regnier, C., Drevillon, M., et al., 2018. Recent updates on the Copernicus Marine Service global ocean monitoring and forecasting real-time $1 / 12^{\circ}$ high resolution system. Ocean Sci. 14, 1093-1126. https://doi.org/10.5194/ os-2018-15.

Madec, G., the NEMO team, 2008. NEMO ocean engine. Note du Pôle de modélisation, Institut Pierre-Simon Laplace (IPSL), France, No. 27 ISSN, 1288-1619.

Nowlin, W.D., Whitworth III, T., Pillsbury, R.B., 1977. Structure and transport of the Antarctic Circumpolar Current at Drake Passage from short-term measurements. J. Phys. Oceanogr. 7, 788-802.

Orsi, A.H., Whitworth III, T., Nowlin, W.D., 1995. On the meridional extent and fronts of the Antarctic Circumpolar Current. Deep Sea Res., I 42, 641-673. https://doi.org/10.1016/0967-0673(95)00021-W.

Park, Y.-H., Park, T., Kim, T.-W., Lee, S.-H., Hong, C.-S., Lee, J.-H., Rio, M.-H., Pujol, M.I., Ballarotta, M., Durand, I., Provost, C., 2019. Observations of the Antarctic Circumpolar Current over the Udintsev Fracture Zone, the narrowest choke point in the Southern Ocean. J. Geophys. Res. Oceans 124, 4511-4528. https://doi.org/10.1029/ 2019JC015024.

Peña-Molino, B., Rintoul, S.R., Mazloff, M.R., 2014. Barotropic and baroclinic contributions to along- and across-stream transport in the Antarctic Circumpolar Current. J. Geophys. Res. Oceans 119, 80118028. https://doi.org/10.1002/2014JC010020.

Provost, C., Renault, A., Barré, N., Sennéchael, N., Garçon, V., Sudre, J., Huhn, O., 2011. Two repeat crossings of Drake Passage in austral summer 2006: short term variations and evidence for considerable ventilation of intermediate and deep waters. Deep Sea Res. Part II (25-26), 2497-2784. https://doi.org/10.1016/j.dsr2.2011.06.009.
Provost, C., Kartavtseff, A., Lee, J.H., Sennéchael, N., Lanoisellé, J., Ferrari, R., Koenig, Z., Artana, C., Durand, I., 2019a. Drake currentmeter mooring velocity data (2008-2009). SEANOE. https://doi.org/ $10.17882 / 61214$.

Provost, C., Kartavtseff, A., Lee, J.H., Sennéchael, N., Lanoisellé, J., Ferrari, R., Koenig, Z., Artana, C., Durand, I., 2019b. Drake currentmeter mooring velocity data (2006-2008). SEANOE. https://doi.org/ $10.17882 / 61186$.

Pujol, M.-I., Faugère, Y., Taburet, G., Dupuy, S., Pelloquin, C., Ablain, M., Picot, N., 2016. DUACS DT2014: the new multi-mission altimeter data set reprocessed over 20 years. Ocean Sci. 12, 1067-1090. https:// doi.org/10.5194/os-12-1067-2016.

Renault, A., Provost, C., Sennéchael, N., Barré, N., Kartavtseff, A., 2011. Two full-depth velocity sections in the Drake Passage in 2006Transport estimates. Deep Sea Res. Part II 58 (25-26), 2572-2591. https://doi.org/10.1016/j.dsr2.2011.01.004.

Rio, M.H., Mulet, S., Picot, N., 2014. Beyond GOCE for the ocean circulation estimate: synergetic use of altimetry, gravimetry, and in situ data provides new insight into geostrophic and Ekman currents. Geophys. Res. Lett. 41, 8918-8925. https://doi.org/10.1002/ 2014GL061773.

Sprintall, J., 2003. Seasonal to interannual upper-ocean variability in the Drake Passage. J. Mar. Res. 61, 27-57. https://doi.org/10.1357/ 002224003321586408.

Sokolov, S., Rintoul, S.R., 2009. Circumpolar structure and distribution of the Antarctic Circumpolar Current fronts: 1. Mean circumpolar paths. J. Geophys. Res. Oceans 114, C11018. https://doi.org/10.1029/ 2008JC005108.

Sudre, J., Garçon, V., Provost, C., Sennéchael, N., Huhn, O., Lacombe, M., 2011. Short term variations of deep water masses in Drake Passage revealed by a multiparametric analysis of the ANT-XXIII/3 bottle data. Deep Sea Res. II 58, 25-92. https://doi.org/10.1016/j. dsr22.2011.01.005.

Szekely, T., Gourrion, J., Pouliquen, S., Reverdin, G., 2016. CORA, Coriolis, Ocean Dataset for Reanalysis. SEANOE. https://doi.org/ $10.17882 / 46219$.

Thompson, A.F., Stewart, A.L., Spence, P., Heywood, K.J., 2018. The Antarctic Slope Current in a changing climate. Rev. Geophys. 56, 741770. https://doi.org/10.1029/2018RG000624.

Tracey, K.L., University of Rhode Island, 2015. Data collected by current-and-pressure-recording inverted echo sounders (CPIES) and current meter moorings in Drake Passage as part of cDrake from November 2007 to December 2011, version 1.1.NOAA National Centers for Environmental Information. [Available online at http://data.nodc.noaa.gov/ NCEI Accession 0121256).

Uotila, P., Goosse, H., Haines, K., Chevallier, M., Barthélemy, A., Bricaud, C., Carton, J., Fuckar, N., Garric, G., Iovino, D., Kauker, F., Korhonen, M., Lien, V.S., Marnela, M., Massonnet, F., Mignac, D., Peterson, K.A., Sadikni, R., Shi, L., Tietsche, S., Toyoda, T., Xie, J., Zhang, Z., 2019. An assessment of ten ocean reanalyses in the polar regions. Clim. Dyn. 52, 1613-1650. https://doi.org/10.1007/s00382018-4242-z.

Whitworth, T., 1983. Monitoring the transport of the Antarctic Circumpolar Current at Drake Passage. J. Phys. Oceanogr. 13 (11), 2045 2057.

Whitworth, T., Peterson, R., 1985. Volume transport of the Antarctic Circumpolar Current from bottom pressure measurements. J. Phys. Oceanogr. 15 (6), 810-816. 